\title{
ARTIGOS
}

Dol

dx.doi.org/10.11606/issn.25253123.gis.2020.165057

ORCID orcid.org/0000-0002-9889-4967

PALAVRAS-CHAVE Jean Rouch; performance; corpo; nativo-a(u)tor.

\section{O ANTROPÓLOGO- CINEASTA E 0 NATIVO-A(U)TOR: AS TRANSFORMAÇÕES DE OUMAROU GANDA E PETIT TOURÉ EM EU, UM NEGRO, DE JEAN ROUCH ${ }^{1}$}

\section{LUIS FELIPE KOJIMA HIRANO}

Universidade Federal de Goiás, Goiânia, GO, Brasil, 74001-970 ppgasufg@yahoo.com.br

\section{RESUMO}

Este artigo apresenta a dimensão performática e corporal das personagens de Oumarou Ganda e Petit Touré no filme $\mathrm{Eu}$, um negro, de Jean Rouch (1958). Para além da análise dos enquadramentos, falas e edição, enseja-se dar ênfase à interpretação da dimensão performática, tanto dos gestos corporais e feições faciais quanto da impostação da voz off de Oumarou Ganda e Petit Touré. Se, por um lado, compreender de que maneira a dimensão performática e corporal de Ganda e Touré cria uma mise-en-scène própria, possibilitando pensá-los como nativo-a(u)tores, por outro, analisar o espaço de criação das personagens traz apontamentos para pensar na construção do conhecimento antropológico a partir da relação entre Rouch e seus interlocutores. 


\section{ABSTRACT}

This article presents an analysis of the performatic and bodily dimension of Oumaru Ganda's and Petit Tourés characters in Moi, un noir, by Jean Rouch (1958). More than analyzing camera angles, character speeches and editing, it is proposed to emphasize the interpretation of the performatic dimension, looking at bodily gestures and facial expressions, as well as at Omarou Ganda's and Petit Touré's voice-off impostation. On the one hand, understanding how performatic and bodily dimensions of Ganda and Touré create a particular mise-en-scène enables us to view them as native actors/authors. On the other hand, analyzing the spaces available for Gan-

KEYWORDS

Jean Rouch;

performance; body; native actor-author da's and Touré's creative interventions in the filmmaking will bring new aspects to the considerations on the construction of anthropological knowledge, through the relation between Rouch and his interlocutors.

\section{OS GESTOS E AS LINHAS DO ATOR NO CINEMA}

Este artigo pretende discutir as possibilidades de pensar a construção performática das personagens de Oumarou Ganda e de Petit Touré no filme Eu, um negro, de Jean Rouch (1958/2006). Para além da análise dos enquadramentos, falas e edição, enseja-se dar ênfase à interpretação da dimensão performática, tanto dos gestos corporais e feições faciais quanto da impostação da voz off utilizados por Oumarou Ganda na concepção da personagem Edward G. Robinson, e por Petit Touré na personagem Eddie Constantine. Almeja-se, assim, compreender de que maneira o diálogo travado entre Jean Rouch, Ganda e Touré não apenas produz uma nova forma de interpretação do ator no cinema, mas uma maneira singular de construir o conhecimento antropológico.

Ao conferir atenção à dimensão performática e do corpo, procuro mostrar que Jean Rouch, na medida em que "subvertia as fronteiras"2 entre documentário e ficção em seus filmes, extrapolava as fronteiras entre nativo e ator. Além disso, ele borrava as distinções traçadas entre o ator na ficção e no documentário; e entre o cinema e o teatro. Em outras palavras, Jean Rouch não apenas dá um novo estatuto à relação antropólogo-nativo em seus filmes, numa espécie de "antropologia simétrica avant la lettre", como pontua Marco Antonio Gonçalves (2008, 20-21), mas, ao fazer isso, ele também dá outro calibre ao personagem e ao ator no cinema. Poderíamos chamar esse novo estatuto de ator-autor, capaz de imprimir uma mise-en-scène própria ao filme, tal como o cineasta-autor.

2. Nesse sentido, nada mais apropriado do que o título do documentário Jean Rouch: subvertendo fronteiras, de Ana Lúcia Ferraz, Edgar Teodoro da Cunha, Paula Morgado e Renato Stutzman (2000). 
Para seguir essa hipótese, precisamos lembrar que, do início do século XX até a década de 1940, as teorias sobre o cinema desconsideraram 0 papel do ator e da atriz no cinema. ${ }^{3}$ Exemplos disso são os experimentos de Lev Kuleshov, ${ }^{4}$ os escritos de Luigi Pirandello (1925), Rudolf Arnheim $(1957)^{5}$ e Walter Benjamin (1987) - que argumentavam sobre a alienação do ator em relação à sua imagem -, e a possibilidade de que cenas filmadas em contextos totalmente diferentes pudessem ser editadas para compor um mesmo contexto narrativo. Em suma, no cinema, o ator representaria sempre a si mesmo, diferentemente do teatro, que exigiria do intérprete uma versatilidade maior para atuar em diferentes papéis.

Há uma discussão mais contemporânea sobre isso. No cinema, como define Barry King (1985), há um processo de personificação entre o ator e seu papel, ao passo que, no teatro, o processo é de despersonificação. ${ }^{6}$ o primeiro diz respeito ao uso de características corporais e gestuais do ator para constituir um mesmo tipo idiossincrático ao viver diferentes personagens. Em contraposição, a despersonificação se refere ao intérprete que se despoja de suas características mais marcantes para adentrar papéis, a ponto de não o reconhecermos por trás das personagens.

Por fim, atenções diferentes são mobilizadas em cada caso: a edição cinematográfica privilegiaria a visão (inclusive de detalhes em plano próximo) que o espectador tem das personagens, ao passo que, no teatro, a impostação da voz se torna mais importante do que o olhar, muitas vezes distanciado, de quem senta na plateia.

3. Uma rara exceção nesse período é Sergei Eisenstein (1957), que faz uma profunda discussão sobre os modos de atuar no cinema e no teatro, bem como na formação de atores japoneses no teatro Kabuki. A discussão realizada por ele valeria um outro artigo, extrapolando os objetivos do presente texto. Agradeço a Sylvia Caiuby Novaes por ter me apontado a discussão de Eisenstein sobre o ator no cinema.

4. O próprio Lev Kuleshov reconheceria que o papel do ator era fundamental na linguagem cinematográfica. Ao comentar uma experiência pouco conhecida, realizada entre 1916 e 1917, ele descobriu que, utilizando dois atores, um mais hábil do que o outro, e intercalando cenas desses intérpretes numa mesma sequência de imagens, o resultado semântico era diferente. Kuleshov $(1974,192)$ concluiu que, por meio da montagem clássica, nem sempre é possível alterar o trabalho semântico de um ator.

5. Pirandello e Arnheim são autores mencionados por Walter Benjamin (1955) para argumentar sobre a alienação do ator no cinema.

6. A noção de despersonificação, de acordo com Barry King $(1985,30)$, vem do teatro e estabelece que: "ao atuar qualquer personagem a personalidade 'real' do ator deve desaparecer do papel, ou, se inversamente, a gama de atuação está limitada por partes consoantes com a personalidade do ator, então, isso constitui uma atuação pobre. Essa última, caracterização negativa e oposta, eu irei me referir, de agora em diante, de personificação". No original: "in playing any character, the 'real' personality of the actor should disappear into the part or, conversely, that if the range of the actor is limited to parts consonant with his or her personality then this constitutes 'poor' acting. This latter, negatively value converse, I shall refer to, hereafter, as personification". King não objetiva referendar essa hierarquização na forma de atuar, mas justamente mostrar em seu artigo que a personificação no cinema e na televisão não significa necessariamente uma atuação fraca; pelo contrário, diz respeito à própria característica desses meios, que requerem do ator e da atriz que suas características físicas e pessoais sejam elementos constitutivos do papel a ser encenado. 
Essas diferenças, ainda que fundamentais para uma época em que se perguntava sobre a singularidade da sétima arte em relação às outras, são um tanto quanto estanques e exprimem uma distinção graduável, mais do que uma diferenciação hermética. 0 que procuro mostrar, a partir da análise de Eu, um negro, é como os filmes de Jean Rouch possibilitam um espaço de construção autoral do nativo-ator, criando um novo calibre para pensar o ator no cinema e o nativo na antropologia, o que terá ressonâncias na Nouvelle Vague e na antropologia contemporânea, como menciono brevemente ao final do artigo. Algumas perguntas ajudam a ver a dificuldade de aderir a essas definições, não só em $E u$, um negro, mas também em Jaguar (1967) e Crônica de um verão (1961), entre outros filmes do diretor.

Oumarou Ganda, em Eu, um negro, ao performar Edward G. Robinson, estaria representando a si mesmo? E o que dizer de Petit Touré, chamado, no filme, de Eddie Constantine, no papel do agente federal americano Lemmy Caution? Seria esse um processo de personificação de si mesmo numa personagem ou de despersonalização? Seria o jogo de olhar mais importante na construção da personagem do que a voz, sincronizada a posteriori? Evidentemente, essas são questões retóricas que servem para ilustrar o quanto determinadas formulações, outrora canônicas nos estudos de cinema, ficam sem uma resposta simples diante da produção cinematográfica de Jean Rouch.

É interessante notar como a discussão sobre o papel do ator no cinema ganhava importância no período em que Rouch filmava. A possibilidade de rodar planos-sequência mais longos, conforme notou o renomado crítico André Bazin (2006; 2018), dos Cahiers du Cinema, abriu espaço para interpretações mais livres dos atores e atrizes, sem que os cortes interrompessem sua atuação. Um exemplo disso, conforme Bazin (2006), seriam os filmes de Orson Welles, que construía a direção a partir dos atores. Também Rouch e seus intérpretes se valeram desse recurso.

Se, atualmente, o papel do ator é reconhecido pelos estudos de cinema como um aspecto importante na construção de um filme, ainda há poucas análises que se debruçam sobre os usos e as técnicas corporais dos intérpretes como elementos fundamentais da narrativa cinematográfica. Baron e Carnicke (2008) fornecem uma metodologia interessante de análise dos atores e atrizes no filme. Elas argumentam que a verossimilhança de uma interpretação se constitui no uso da musculatura corporal e da voz num ritmo, frequência, fluxo e força que dão corpo aos conflitos do enredo, dentro dos limites do aparato cinematográfico. Nesse sentido, há que se atentar para: 1) o uso do espaço do ator no enquadramento da cena; 2) o tempo: a velocidade e o ritmo dos gestos numa sequência fílmica; e 3) o peso e a força no uso do corpo, na contração e 
no relaxamento da musculatura. Tais procedimentos corporais de uso do espaço e do tempo sinalizam o modo como o ator corporifica o enredo, revelando, nas minúcias, abrangências e variações dos gestos, os conflitos pessoais da personagem.

Para um antropólogo, é difícil não perceber na proposta de Baron e Carnicke (Ibid.) um diálogo possível com o clássico ensaio de Marcel Mauss (1934/2003), As técnicas do corpo. Os modos de usar o corpo, como ensina Mauss, são culturalmente adquiridos, e o cinema seria um meio de transmissão de técnicas corporais, como ele explica por meio do conhecido exemplo da influência das atrizes dos filmes estadunidenses no modo de andar das jovens francesas. Em suas análises, Baron e Carnicke (op. cit.) mostram como as técnicas de atuação se modificam ao longo do tempo, como atestam as diferentes adaptações de Romeu e Julieta para o cinema, ou as diferenças que emergem na comparação do filme Os sete samurais, de Akira Kurosawa (1954/2004), com a adaptação do mesmo roteiro feita para o faroeste americano, The magnificent seven (Sturges 1960/2007). São patentes as diferenças culturais na aprendizagem e nos significados das expressões entre as versões japonesa e estadunidense - Kurosawa, por exemplo, se vale de expressões do teatro Nô e da movimentação de palco do teatro de bonecos do Kabuki, algo ausente no faroeste americano.

Os gestos, os modos de andar e as habilidades corporais, como propõe Tim Ingold (2007; 2015), traçam linhas. ${ }^{7}$ Nesse sentido, penso que seria possível realizar uma análise dos filmes a partir das linhas que os atores e atrizes desenham em cada cena. Assim, a continuidade narrativa no cinema clássico hollywoodiano teria priorizado, de uma sequência a outra, o desenho de uma linha contínua visando uma finalidade, ${ }^{8}$ ao passo

7. Segundo Ingold $(2015,4)$ as linhas "nos dão vida. A vida começa quando as linhas começam a emergir e escapam ao monopólio das bolhas. Onde a bolha atesta o princípio da territorialização, as linhas demonstram o princípio contrário o da desterritorialização" (tradução do autor). No original: "give us life. Life began when lines began to emerge and to escape the monopoly of blobs. Where the blob attests to the principle of territorialisation, the lines bear out the contrary principle of deterritorialisation". Ou seja, para ele as linhas permitem aos seres se enredar aos outros seres, nos dando vida e criando vida. As linhas são traçadas com o movimento dos seres, seja por gestos, caminhadas, inscrições, sons, entre outros elementos que deixam traços: desde o momento em que as pessoas estão falando e gesticulando, elas também estão fazendo e seguindo linhas". No original: "ever since people have been speaking and gesturing, they have also been making and following lines" (Ingold 2007, 3).

8. Como nos ensina Ismail Xavier $(2005,153)$, no cinema clássico é "preciso que esse mundo se apresente 'pleno de sentido' e unificado; é preciso que a representação ofereça à consciência a ilusão de que suas operações de síntese, que impõem uma continuidade e uma finalidade às coisas, são essencialmente objetivas. E a continuidade narrativa do cinema clássico é o grande monumento erigido para a satisfação de tais necessidades". Nessa passagem, Xavier comenta a leitura de Jean-Louis Baudry, da revista Cinémathique, sobre o cinema clássico, com a qual ele se contrapõe ao argumentar que a ideia de uma transparência da imagem em relação à realidade seria uma ideologia burguesa. A proposta de Baudry e da revista é de um cinema de desconstrução do cinema clássico. 
que movimentos como a Nouvelle Vague e o Cinema Novo buscariam uma narrativa com linhas descontínuas, em diferentes direções. Seguindo com Ingold (2007; 2015), na medida em que as linhas narram histórias, considero que, no cinema, as linhas traçadas de uma cena a outra realizam uma trama, história que reside no modo com que as linhas se enredam. Se linhas delineadas pelos movimentos dos atores e atrizes são elementos centrais na edição das sequências de um filme, em cada sequência as linhas expressam os sentimentos das personagens, em seus rostos, mãos, braços e pernas, movendo-se conforme a força, a fluidez e a contração do movimento do corpo, em planos próximos ou distantes.

Proponho focalizar essa dimensão de Eu, um negro, além do enquadramento, da edição e da voz, a fim de mostrar como, nesse filme, Jean Rouch, Oumarou Ganda e Petit Touré produzem uma nova forma de interpretação do ator no cinema para, posteriormente, trazer apontamentos desse diálogo no que tange à produção do conhecimento antropológico.

\section{AS CONDIÇÕES DE FILMAGEM E ANTIDIREÇÃO DE ATOR DE ROUCH}

Convém lembrar que $\mathrm{Eu}$, um negro foi filmado com uma câmera Bell\&Howell de $16 \mathrm{~mm}$, cujos planos não duravam mais do que $25 \mathrm{se}-$ gundos (Gonçalves op. cit.), o que restringiu o tempo dos planos-sequência nos quais Oumarou Ganda e Petit Touré se moviam. Entretanto, diante dessa limitação e da impossibilidade de captação sincrônica do som e da imagem, Rouch transformou as dificuldades técnicas em potência, dando o microfone para Ganda e Touré interpretarem a própria atuação. Além disso, ele buscou dotar as imagens de grande profundidade de campo e estendeu os planos-sequência na edição.

Conforme Alexandrine Boudreault-Founier, Rose Hikiji e Sylvia Caiuby Novaes $(2016,40)$, Rouch nos ensina que o diretor não é soberano diante do documentário, o que "implica necessariamente um espaço de liberdade de atuação para aqueles que são filmados e mais: implica colaboração entre quem filma e quem é filmado".

No caso de Rouch, essa afirmação não poderia ser mais verdadeira. Segundo Paul Henley (2009), o diretor tinha uma ideia geral do roteiro do filme, mas nunca de forma escrita. Era um "roteiro conforme a tradição oral”, como chamou Philo Bergstein (apud Ibid., 261), um de seus colaboradores. A oralidade do roteiro permitia o improviso e a recriação dos atores sobre a ideia geral proposta por Rouch. Em Petit à petit, por exemplo, Safi Faye lembra que Rouch se recusou a dirigi-la em cena, embora ela lhe pedisse para fazê-lo. Ainda de acordo com Henley (Ibid.), a regra de ouro da etnoficção era a filmagem cronológica das cenas, com uma tomada e um ângulo por cena. Antes da tomada, o que os atores faziam era experimentar o espaço e suas possibilidades. Não se tratava propriamente 
de um ensaio, e isso se dava para que a improvisação e o inesperado pudessem eclodir. Em Eu, um negro, conforme a apresentação feita por Rouch (op. cit.) no início do filme, o roteiro se resumia à orientação para que os atores performassem eles mesmos; era um espaço "onde podiam fazer de tudo e dizer de tudo". Talvez nisso resida a forma como Rouch visa atingir aquilo que Ana Lúcia Ferraz (2013) identificou como uma dimensão patética em seus filmes: o improviso e o inesperado como um processo de dramatização para chegar a outra condição.

Percebe-se nesse método de filmagem de Rouch, por um lado, a adesão ao trabalho de campo etnográfico de seguir aquilo que os nativos fazem e dizem. Talvez seja por isso sua insistência em não dirigir os atores-nativos. Por outro lado, o antropólogo-cineasta compartilha da noção de que uma etnografia se sustenta a partir de uma narrativa, visando, assim, uma filmagem cronológica cena por cena, mas onde o improviso pudesse eclodir o inesperado, dotando a narrativa de dramaticidade.

Em Eu, um negro a colaboração e o improviso se iniciaram com a escolha das pessoas que iriam participar do filme, intermediada pelo próprio Oumarou Ganda, que apresentou Rouch a moradores de Abidjan durante as filmagens e o processo de captação do som. Como rememorou Rouch: "Nós pusemos juntos a narração em dois dias para um filme que tinha duas horas de duração naquele momento. [Ganda] estava encantando e por isso pôde atuar bastante na narração" (Rouch apud Gonçalves op. cit., 120).

Rouch buscava em seus filmes uma narrativa ancorada no improviso e no inesperado, a partir de um roteiro conforme a tradição oral, e no despojamento de sua soberania como diretor do filme, o que resultava em uma grande liberdade dos atores para intervir no roteiro oral e na sonorização pós-filmagem. É nesse sentido que se torna possível pensar numa produção compartilhada de seus filmes e nos atores-nativos também como autores. Isso, entretanto, não surge de maneira explicita nos créditos de apresentação do filme, mas aparece de outras formas: antes da apresentação dos letreiros encabeçado por "Um filme de Jean Rouch", o diretor, em voz off, apresenta Oumarou Ganda e Petit Touré, e diz, no plural, que "foi assim que improvisamos esse filme". Essa autoria compartilhada, como veremos, também aparece no uso da voz off, dividido entre Rouch, Ganda e Touré, no modo como narram e interpretam as imagens do filme. É interessante notar, do ponto de vista estritamente antropológico, que a narração de Ganda e Touré sobre as imagens equivaleria a colocar a interpretação do nativo sobre um texto etnográfico do antropólogo, algo que apenas ocorreria, de modo mais sistemático, a partir dos anos 1980 nas etnografias pós-modernas e contemporâneas, em que se procura uma autoria compartilhada e dar "voz" 
ao nativo (Marcus 1991). ${ }^{9} \mathrm{~A}$ imagem, para Rouch, nesse sentido, tinha o poder de propiciar a participação dos nativos que não falavam ou liam a linguagem acadêmica das monografias etnográficas. Mas, antes de adentramos a discussão da produção do conhecimento antropológico, vejamos mais detidamente como a produção colaborativa de Eu, um negro se expressa na voz, nos gestos e no corpo Ganda e Touré.

\section{LINHAS DE OUMAROU GANDA E PETIT TOURÉ}

De forma bastante resumida, o filme $\mathrm{Eu}$, um negro narra o cotidiano de jovens imigrantes nigerinos, como Edward Robinson e Eddie Constantine, em Abidjan, na Costa do Marfim, à procura de emprego. Imersos na rotina de trabalho pesado como carregadores e vendedores ambulantes, nos momentos de lazer dos finais de semana, as vozes off de Ganda e Touré introduzem a dimensão subjetiva das suas frustrações e sonhos: o desejo de ter carros, mulheres e dinheiro, tal como os astros de Hollywood.

Oumarou Ganda, no momento em que participa do filme, é auxiliar de pesquisa de Rouch. Em Eu, um negro, ele desempenha o papel de si mesmo, imigrante que foi antes de trabalhar para o antropólogo-cineasta. Mas esse papel de imigrante, no contexto do filme, já não é o mesmo. Ganda adiciona a ele uma dimensão onírica através de Edward G. Robinson, um ator de sucesso hollywoodiano.

Já Eddie Constantine, conforme Gonçalves (op. cit.), era ele mesmo um ator e cantor que, na década de 1950, participou, no papel do detetive Lemmy Caution, de mais 30 filmes do gênero policial-humorístico. Em Eu, um negro, de modo paradoxal, ele performa Petit Touré, um imigrante: um vendedor ambulante que deseja ser ele mesmo, o ator que encena o detetive Caution. Trata-se, enfim, de uma espécie de sonho inverso de si próprio.

É interessante notar que Oumarou Ganda, o ator amador - aquele que supostamente forneceria um maior coeficiente de realidade documental ao filme (pois foi imigrante) -, ganhou mais espaço na versão editada do que Petit Touré, visto que ambos são performers tanto de si mesmos (imigrantes, atores) quanto de outros (atores, imigrantes) na produção. Os dois são índices com lastro documental e ficcional, ao mesmo tempo. Há, nisso tudo, um sentido de composição que ultrapassa as classificações mais estreitas de cada gênero. Outro aspecto importante dessa configuração é que ela aproxima as figuras do ator e do imigrante. Cria-se, então, uma imagem do ator como um imigrante no interior dos filmes - alguém que percorre muitos caminhos, que vai a muitos lugares, que cruza fronteiras. Será o ator, num filme, sempre um clandestino, num território criado por outra pessoa (um diretor), que ele tenta modelar à

9. Retomo brevemente essa complexa discussão no final do artigo. 
sua maneira, intervindo como o imigrante em sua nova casa? E, vice-versa, o filme convida a perguntar: não seriam os imigrantes sempre atores de si mesmos em outros contextos, buscando frestas por onde passar para ampliar o alcance de suas existências? ${ }^{10}$

Uma sensação de verossimilhança se expressa com força na narração em voz off de Ganda, que modula tanto o sorriso e a alegria de participar de um filme, na abertura de $\mathrm{Eu}$, um negro (Figura 1), quanto a tristeza e a revolta que ganham espaço no decorrer da narrativa (Figura 2). Eddie Constantine, apesar de compartilhar com Edward Robinson o amor pelas mulheres e o desejo de ter dinheiro, concretiza os seus desejos de modo diferente do amigo: ele leva uma vida cotidiana em melhores condições, como vendedor ambulante e, com isso, termina a noite de sábado com Nathalie, alimenta-se num restaurante e corta o cabelo no salão (Figura 3). No entanto, conforme anunciado desde o início do filme, ele leva tão a sério o papel de agente federal americano que termina preso por três meses.

FIGURA 1

Oumarou Ganda em sua primeira aparição no filme. Fonte: Eu, um negro, de Jean Rouch (1958/2006).

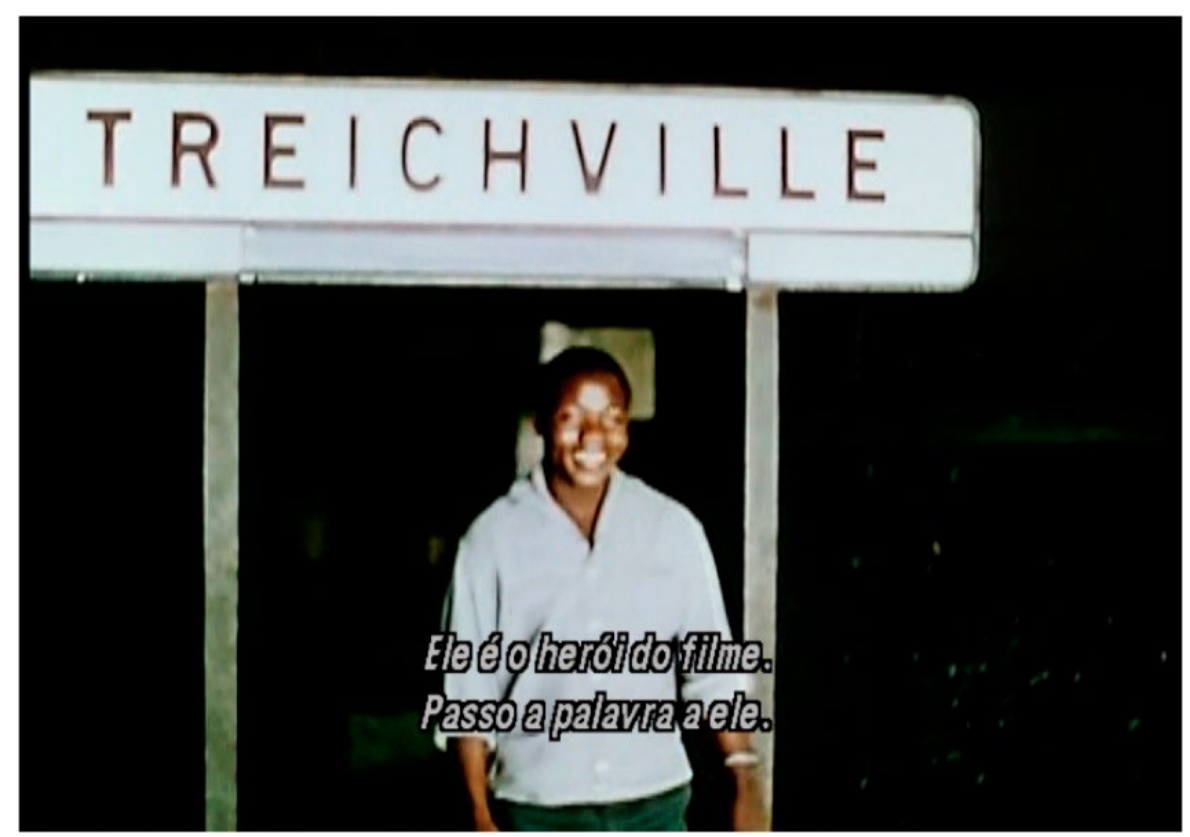

10. Agradeço a Tatiana Lotierzo (2019) por essa reflexão, que também dialoga com as questões apresentadas em sua tese Erosão num pedaço de papel. Outro tema colocado através dessa configuração, conforme ela sugere, é o da colonização: o diretor branco é, no fundo, ele próprio o forasteiro na Costa do Marfim, em um ou muitos territórios que não lhe pertencem (o país, as vidas ali presentificadas), dos quais busca reivindicar um quinhão por meio do documentário. 0 território não lhe pertence, mas é figurado como seu no filme (visto que ele estaria em posse de "sua criação"). Ao mesmo tempo, os atores são expostos ali como imigrantes, desterrados de seus lugares de existência; contudo, retomam a propriedade sobre a própria existência ao intervir na trama. Essa análise vem sob inspiração de suas aprendizagens com o artista inga Benjamín Jacanamijoy (Lotierzo, 2019), que também intervém em territórios de um Tempo dos pensamentos roubados - sua maneira de traduzir "colonização". 
FIGURA 2

Apresentação de Eddie Constantine.

Fonte: $E u$, um negro, de Jean Rouch (1958/2006).

FIGURA 3 Eddie Constantine indo comer no restaurante.

Fonte: $E u$, um negro, de Jean Rouch (1958/2006).
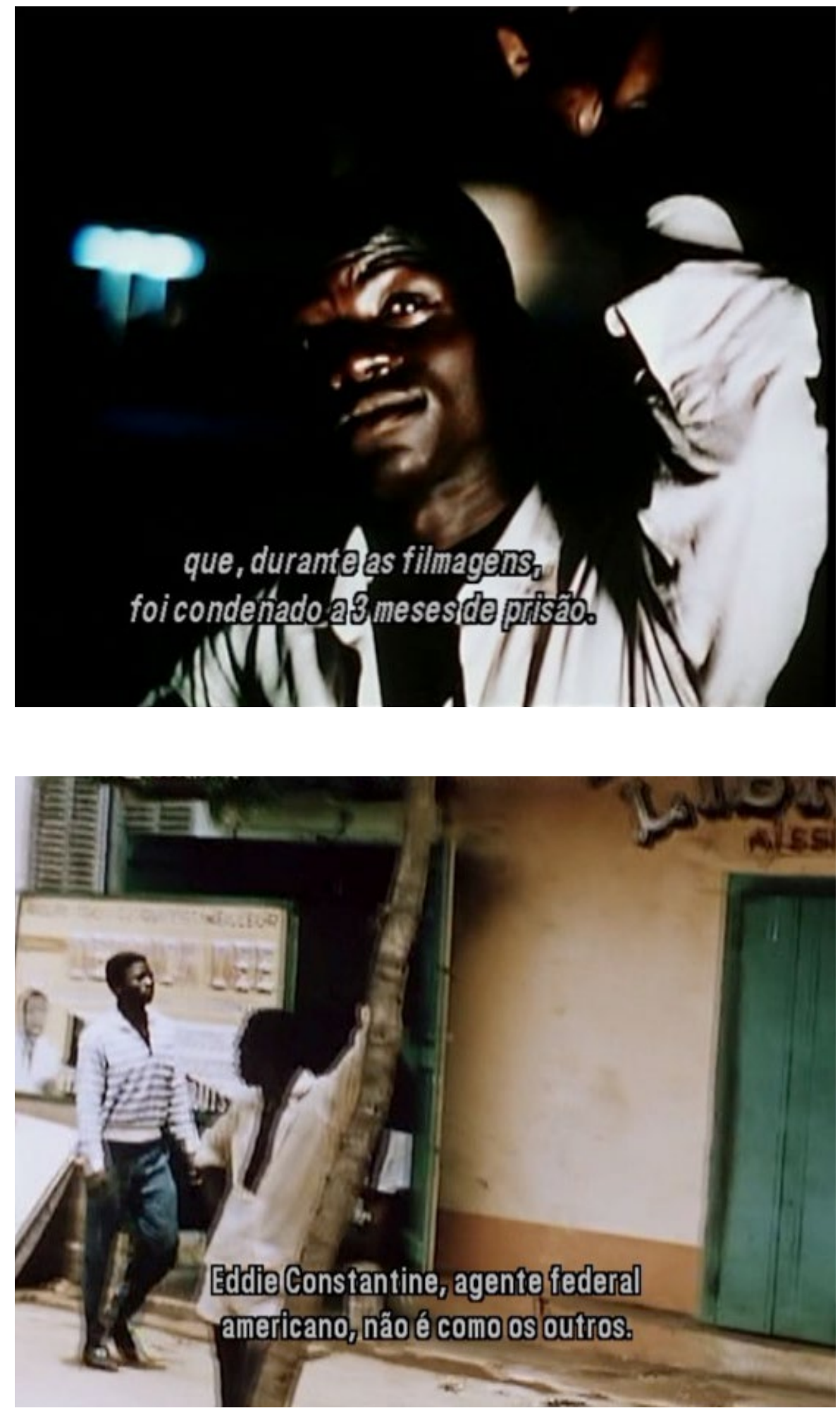
O infortúnio de Eddie Constantine não é o centro da narrativa. Ele constrói seu personagem como um vendedor e agente calmo, cujas feições faciais não revelam sulcos que expressem dor. Sua musculatura do rosto é leve e ele sempre tem um ligeiro sorriso no rosto (Figura 4). Sua postura também é ereta e retilínea, com pisadas leves ao andar. A impostação da voz, na fala em francês com sotaque americano, tem volume mais baixo e sem grandes modulações. Petit Touré constrói, com Eddie Constantine, a figura de um conquistador que não perde a pose, ao menos nas sequências filmadas e na maneira de falar. A notícia de sua prisão no início e no fim do filme é uma maneira de quebrar expectativas, guardando um certo distanciamento para a personagem que ele constrói para si.

É possível dizer que Edward G. Robinson é um simétrico inverso de Eddie Constantine. Para Robinson, tudo dá errado no decorrer da narrativa, o trabalho não lhe garante a satisfação de seus desejos, as mulheres não lhe dão atenção, e os momentos de lazer o fazem lembrar o quanto a alegria é fugaz. É apenas na dimensão do devaneio, quando se torna o boxeador Edward Ray Sugar Robinson e quando retorna às lembranças fabuladas da Guerra da Indochina, que vemos Robinson sorrir espontaneamente. Para ele o cotidiano é maçante e o sonho lhe permite ser outro; para Constantine, o cotidiano seria o sonho e ser outro tão verdadeiramente se torna um pesadelo.

FIGURA 4 Eddie Constantine dançando com serenidade. Fonte:

Eu, um negro, de Jean Rouch (1958/2006).

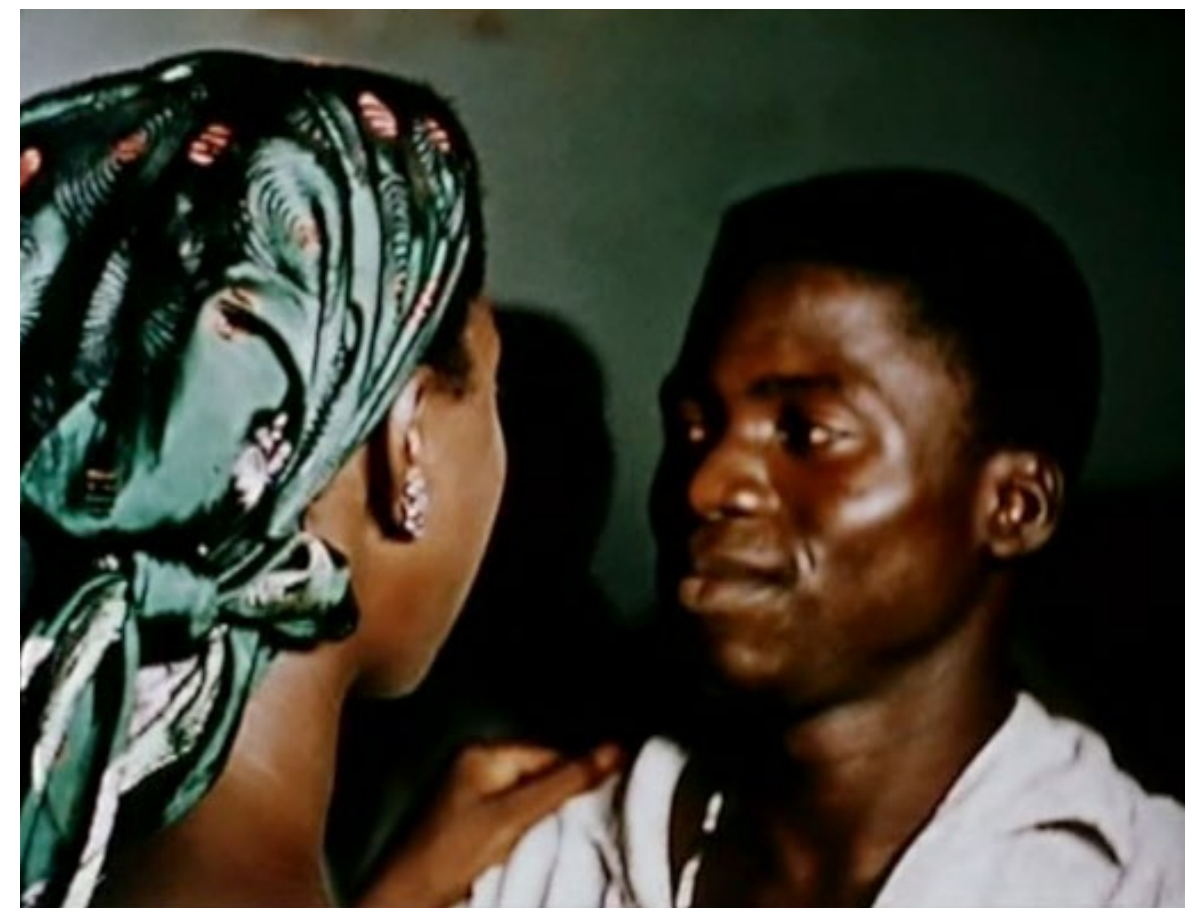


É importante abrirmos um parêntesis para compreender a concepção de sonho rouchiana, pois isso permite aquilatar melhor a composição das personagens no filme. Segundo Gonçalves (op. cit.), Rouch pensa o sonho a partir de sua experiência como antropólogo e de seu diálogo com as vanguardas artísticas. Entre os Dogon, Rouch aprendeu a "ffazer de conta' que o que dizemos é verdade... fazendo de conta ficamos mais perto da realidade" (Rouch apud Ibid., 111) - o que ele entendeu como uma maneira de fabular histórias que se tornaria presente em seus filmes.

Além disso, há uma inspiração surrealista do diretor: "a ideia de Rouch sobre o sonho se confunde mesmo com a definição de uma 'filosofia surrealista" (Ibid., 122) em que, como escreve Élouard, "é a esperança ou desesperança que determinará para o sonhador [...] a ação de sua imaginação" (Élouard 1939, 81 apud Ibid., 122). o filme Os esquecidos (1950), de Luis Buñuel, seria uma referência para Rouch, que via o diretor surrealista como alguém que sabia "cruzar as barreiras entre sonho e realidade... o sonho é como o real, talvez mais do que realidade. Foi o que eu tentei fazer em $\mathrm{Eu}$, um negro, [...] pular entre dois" (Rouch apud Ibid., 122).

A modulação entre o sonho e a realidade é visível na construção expressiva de Robinson. Oumarou Ganda e Rouch criam uma personagem complexa, que exprime, na maior parte do filme, uma tonalidade de tristeza e revolta contra o mundo que o cerca. Na primeira imagem de $\mathrm{Eu}$, um negro, Robinson aparece sorrindo e dando boas-vindas aos espectadores, em plano médio. Sua segunda aparição, em close, mostra uma expressão endurecida, com cenho franzido e sobrancelhas para baixo (Figuras 5, 6 e 7). Passamos a seguir seus passos incertos pela cidade, à procura de trabalho, e seu andar é arqueado, levemente curvado para dentro. Os braços se movem, por vezes, de modo desajeitado, assim como a cabeça que, de quando em quando, se vira impacientemente de um lado para o outro. Esses movimentos são reforçados por uma edição que explora sequências em que ora ele surge da esquerda para direita, ora de baixo para cima, ora em direção invertida. Suas expressões e movimentos corporais não desmentem o que ouvimos em sua voz off: "A vida é complicada! A vida é triste! Alguns moram bem, comem bem... Mas eu... vivo do outro lado, vivo em Treichville. Nossas casas são barracos... Nossas vidas são diferentes...", ele diz (Rouch op. cit.). Essa voz é modulada, entre a baixa e a alta intensidade, entre reticências e exclamações. Por vezes, Robinson deixa escapar um riso irônico quando fala do quão caras são as coisas para ele.

As diferenças na composição das personagens de Oumarou Ganda, como Robinson, e Petit Touré, como Constantine, talhadas por eles mesmos e por Rouch, resultam em um retrato diversificado dos migrantes nigerinos, algo extremamente inovador no que tange à construção 
de personagens negros no cinema brasileiro, europeu e estadunidense (Hall 1997, Hirano 2013; 2019, Stam e Shohat 2006). Ao diversificar os desejos e ocupações desses imigrantes, Rouch, Ganda e Touré individualizam suas personagens, dotando-lhes de subjetividades complexas. É fato que outros retratos são possíveis, como reivindicam atualmente cineastas do continente africano quando se referem a Rouch (Sztutman 2004), dado que, como discute Bhabha (2007), não haverá um porto seguro de identificação entre os espectadores negros e sua representação, uma vez que o processo de significação é movediço, ambivalente e variável, criando um hiato entre as novas e infinitas formas de representação dadas aos brancos em relação aos grupos estigmatizados, quer racialmente ou por sua etnia. o problema do estereótipo é justamente fixar um número limitado de representações sobre grupos raciais e étnicos em constante transformação. Rouch, Ganda, Touré e os outros "eus" desses intérpretes expressam uma multiplicidade presente nas modulações de desejos, sonhos e humores de cada um deles e explora contraposições entre sujeitos. O nome do filme é interessante, nesse sentido: por um lado, realça o marcador racial; por outro, singulariza. Ganda e Touré são "um negro", entre muitas formas possíveis."

FIGURA 5

Oumarou Ganda em close. Fonte:

Eu, um negro,

de Jean Rouch (1958/2006).

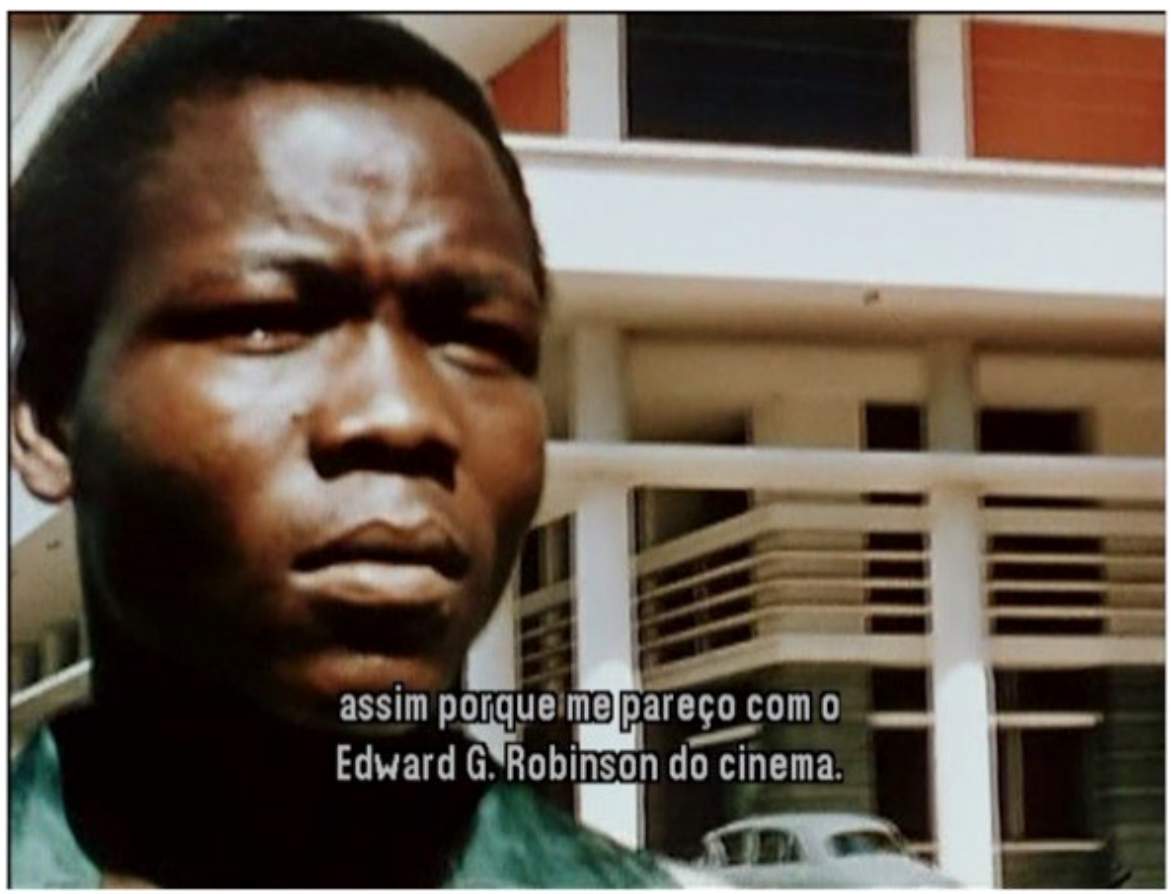

11. A dimensão colonial nos filmes de Rouch é um tema complexo, que valeria outro artigo. Rouch buscou extrapolar as fronteiras em vários sentidos, tanto na relação entre antropólogo e nativo quanto na relação entre cineasta e ator, mas é necessário reconhecer que é ele quem assina o filme, embora o processo de construção tenha sido compartilhado. Se a assinatura do filme revela uma relação de poder, é importante notar que, ao atribuir a autoria para si, ele também se colocava como responsável pelo filme, seja por suas consequências positivas ou negativas. 


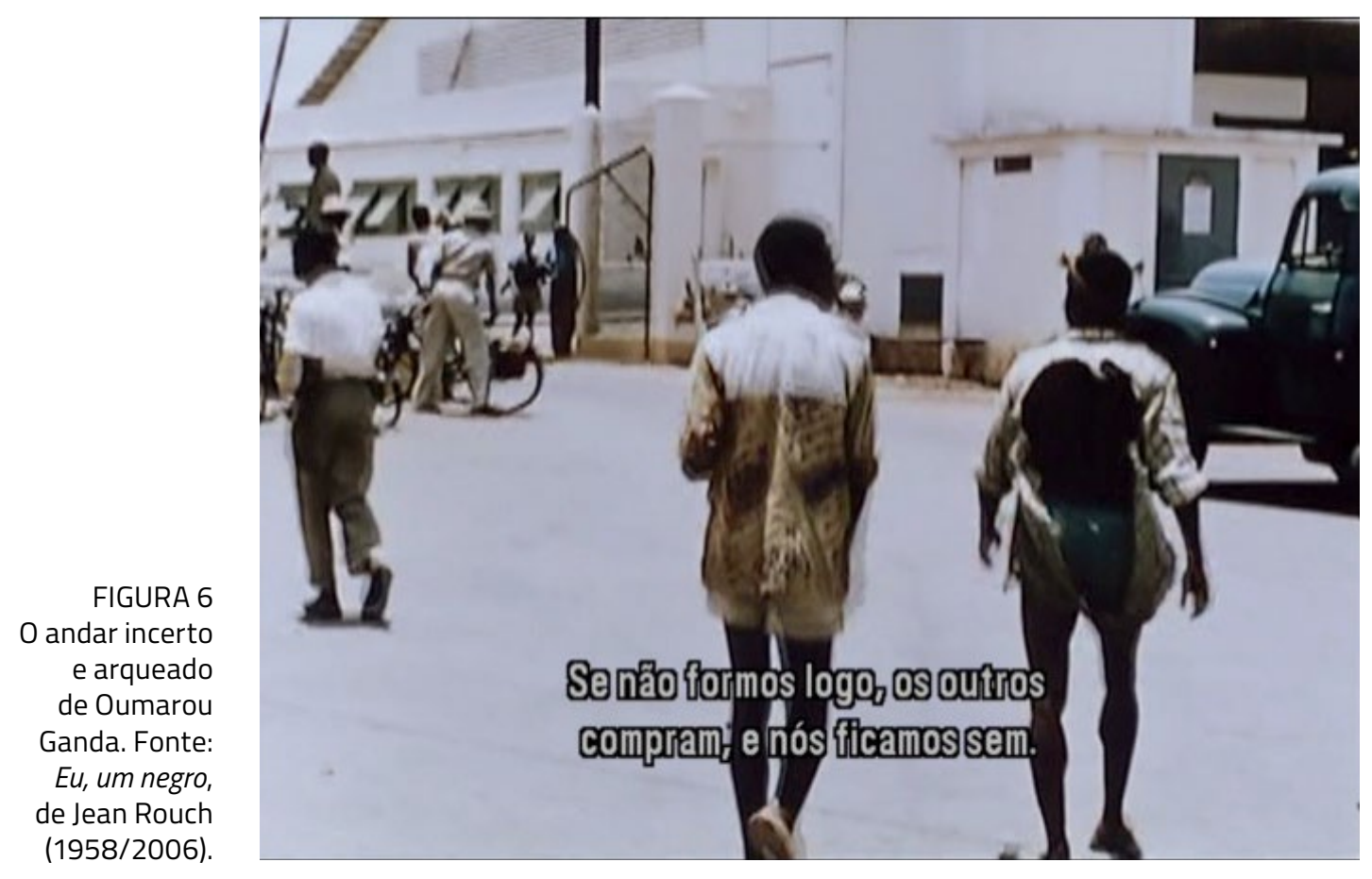

(1958/2006).

FIGURA 7

Comprando o almoço. Fonte: Eu, um negro, de Jean Rouch (1958/2006).

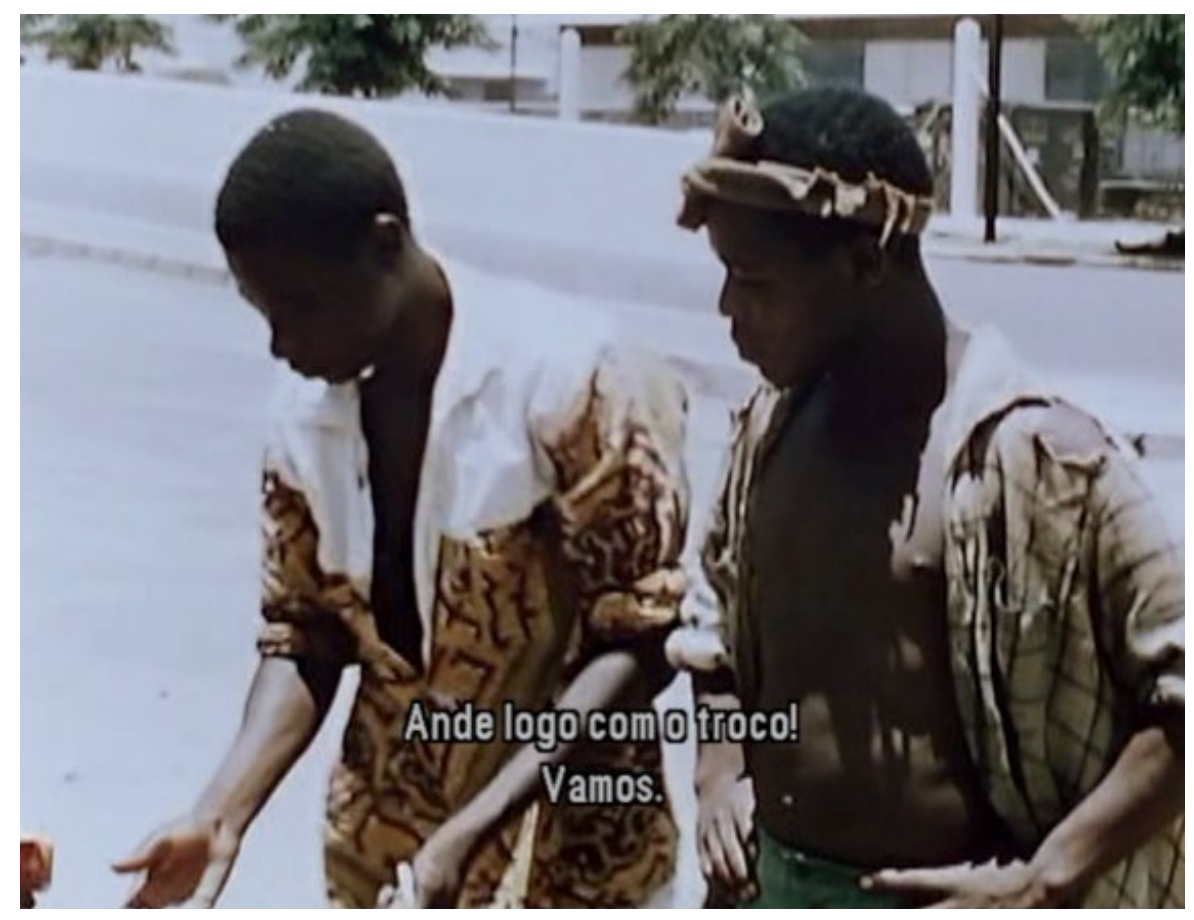


Após o expediente, a caminho de casa, o ar de dureza abre espaço para um lado mais descontraído de Robinson. Em vez de ir ao baile, ele pratica boxe. Vemos nisso uma dimensão de seriedade da personagem, concentrada no aquecimento e em cada golpe. Sobre o fundo escuro, o brilho do suor refletido na pele negra de Robinson, em flashes, cria um jogo de luz e sombra na cena. A sequência, que foi aclamada por Jean-Luc Godard pela beleza estética, expressa o projeto romântico rouchiano de aquisição do conhecimento. Como Anna Grimshaw $(2001,122)$ diz: "o projeto rouchiano se inspira na noção de que a felicidade prospera nas sombras entre a escuridão e a luz". Não à toa, nessa sequência Robinson não fala de tristeza, mas de seus sonhos (Figura 8).

Sob o sol escaldante do sábado, Rouch introduz o fim de semana dos imigrantes nigerinos. Robinson se diverte, mas no momento de descanso ele diz: "todos estão alegres, mas eu estou triste" (Figura 9). Na sequência, uma câmera subjetiva nos leva a uma luta de boxe. Robinson golpeia seu oponente e, em poucos rounds, vence a luta. Essa é a sequência em que Robinson aparece sorrindo por mais tempo (Figura 10). Seu sorriso, no entanto, traz um ar de tristeza, seja pelo que ouvimos dele antes, seja porque ele diz, sobrepondo sua voz à imagem: "infeliz, não sou um boxeador. É apenas um sonho". Sua expressão também traz essa tonalidade. Contrariando o sorriso largo, a marca do retesamento na fronte e os olhos profundos trazem essa carga de sentimentos ambivalentes, tanto na imagem quanto em sua voz, que sintetizam a tensão da trama. De acordo com Rouch, o documentário deveria expressar o céu e o inferno desses jovens: capazes a um só tempo de enfrentar um trabalho árduo e sonhar alegremente (Gonçalves op. cit.).

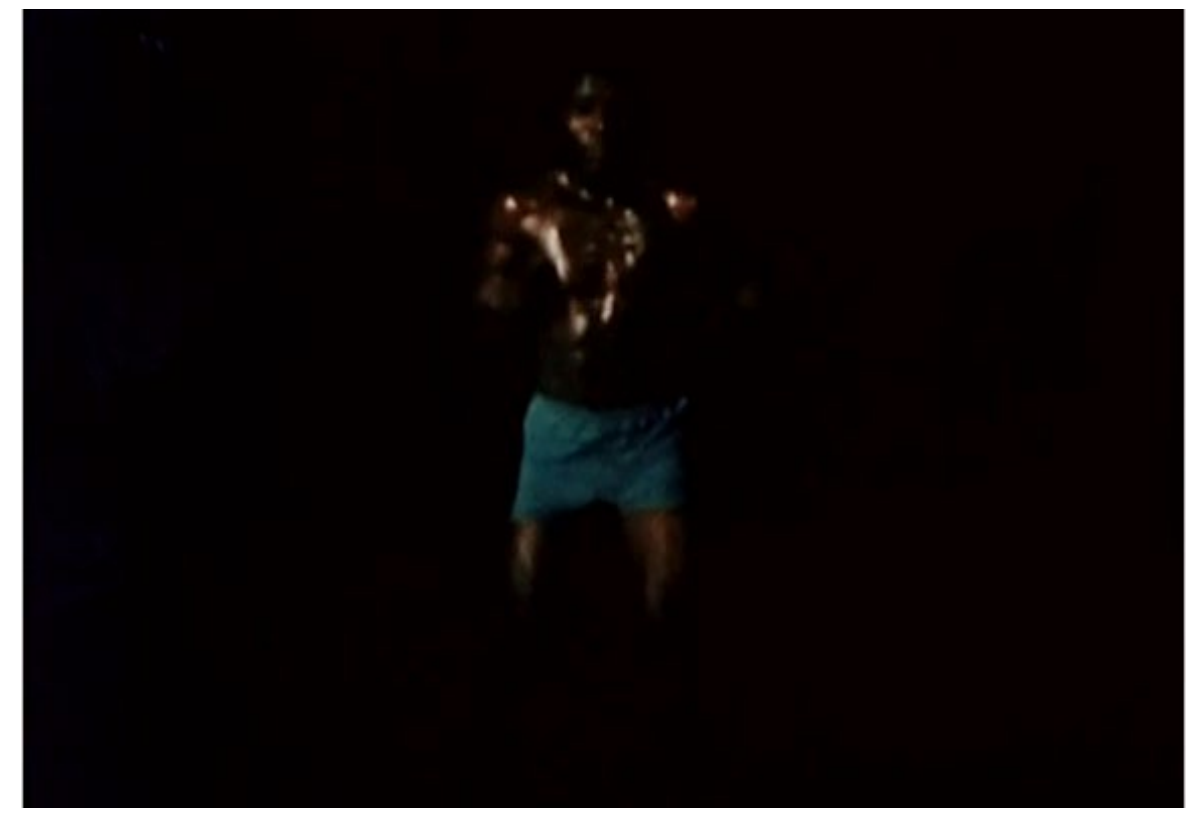




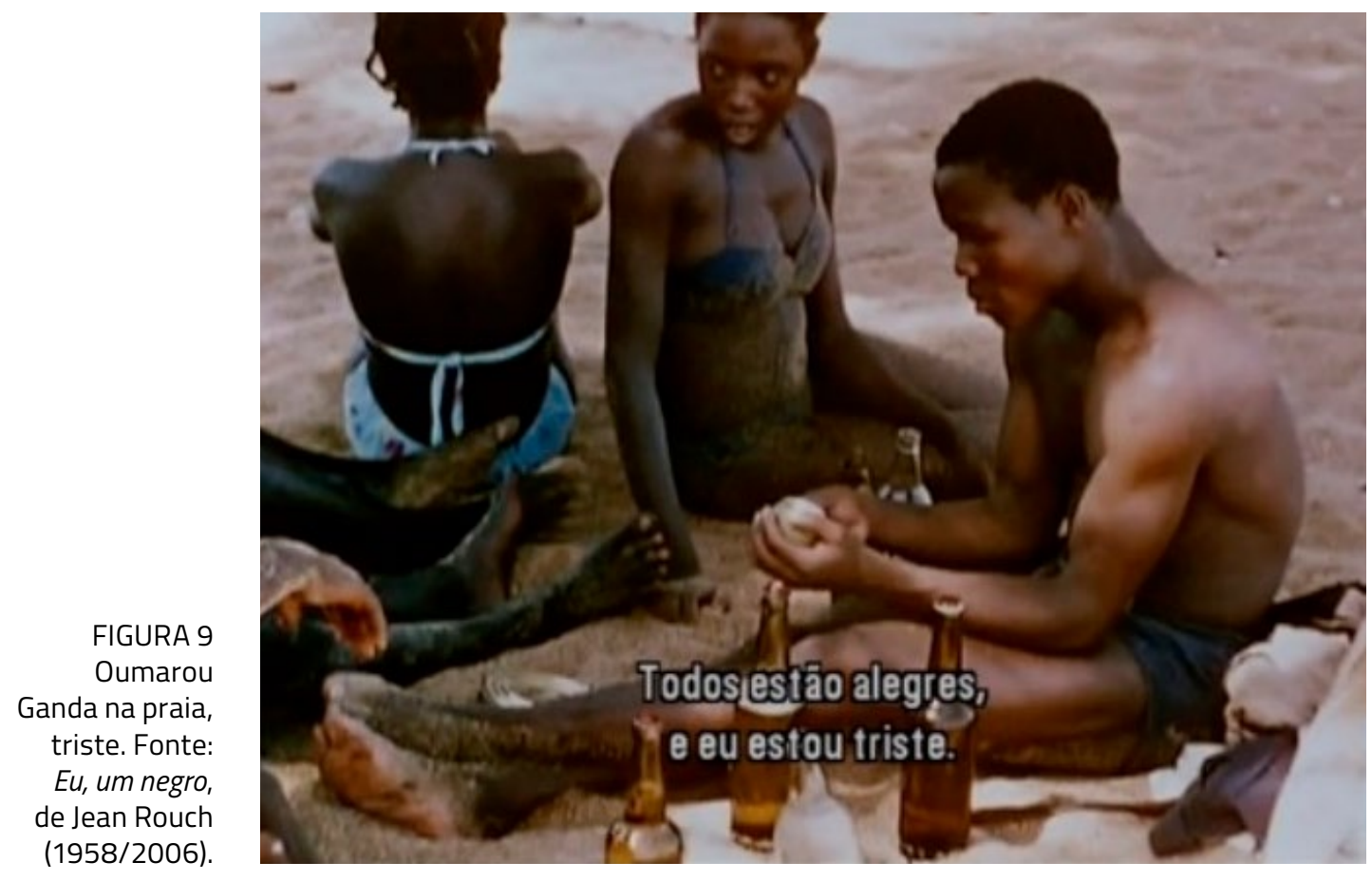

FIGURA 10 Na câmera subjetiva, Oumarou Ganda sonhando a vitória na luta de boxe. Fonte: Eu, um negro, de Jean Rouch (1958/2006).

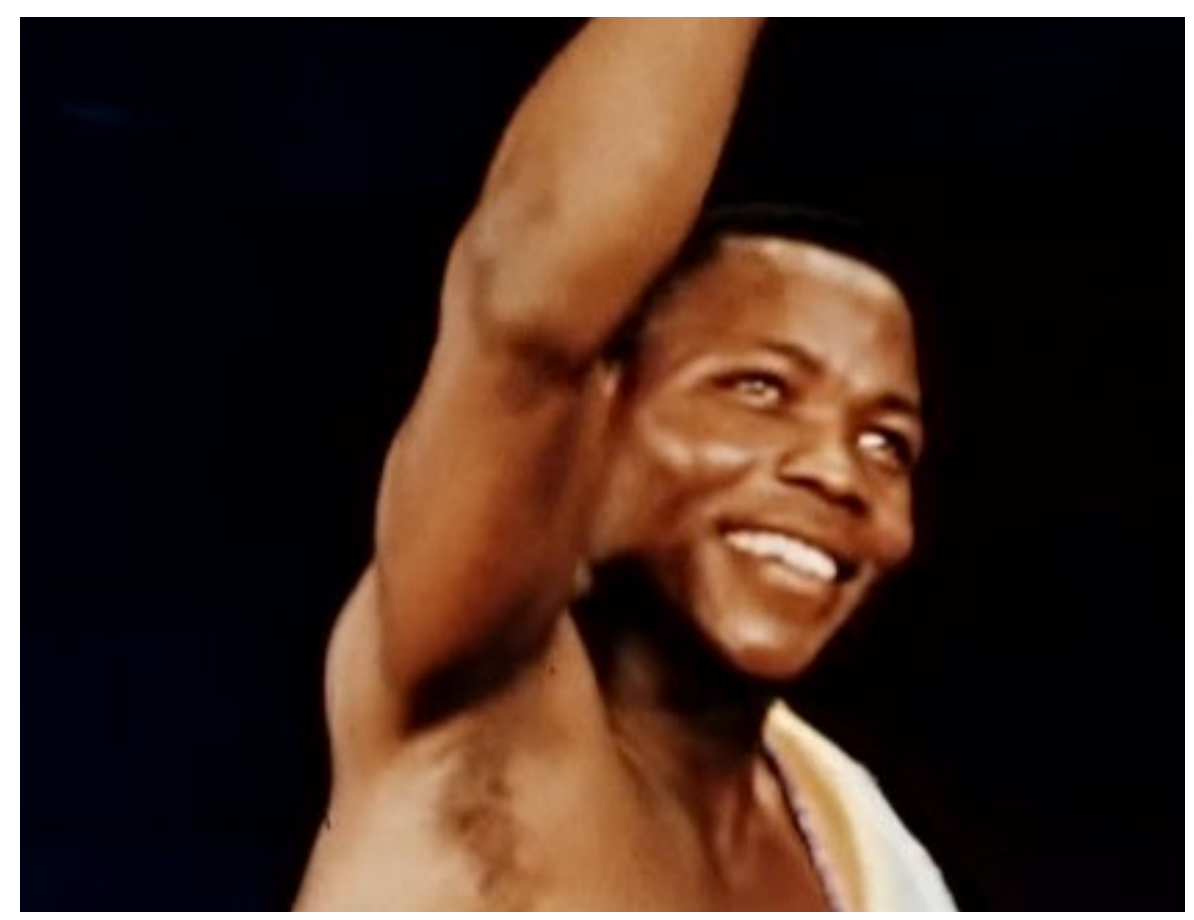

Chega o sábado à noite. Diferentemente de Constantine, que conquista Nathalie, Robinson termina sozinho (Figura 11). No domingo pela manhã ambos vão a uma celebração religiosa: Constantine, para a católica; Robinson, para a mulçumana. À tarde, os dois vão a Goubé ver jovens dançarem e cantarem. À noite, Robinson tenta a sorte com Dorothy 
Lamour, mas é colocado de escanteio por um italiano (Figura 12). Muda de bar, embriaga-se e acaba expulso, sem pagar a conta. No amanhecer de segunda, bate na porta de Dorothy Lamour e é surpreendido pelo italiano. Os dois brigam e Robinson leva uma surra. Na vida real, ele está longe de ser um campeão de boxe. Então retorna ao trabalho e encontra os amigos Elite e Facteur, que contam que Constantine foi preso e vão procurar ajuda para soltá-lo. Robinson encontra Petit Jules - um amigo mais novo - e eles ficam observando um grupo de crianças brincarem na praia, enquanto lembram da infância no Níger.

FIGURA 11 Oumarou Ganda no baile, sábado à noite. Fonte: Eu, um negro, de Jean Rouch (1958/2006).

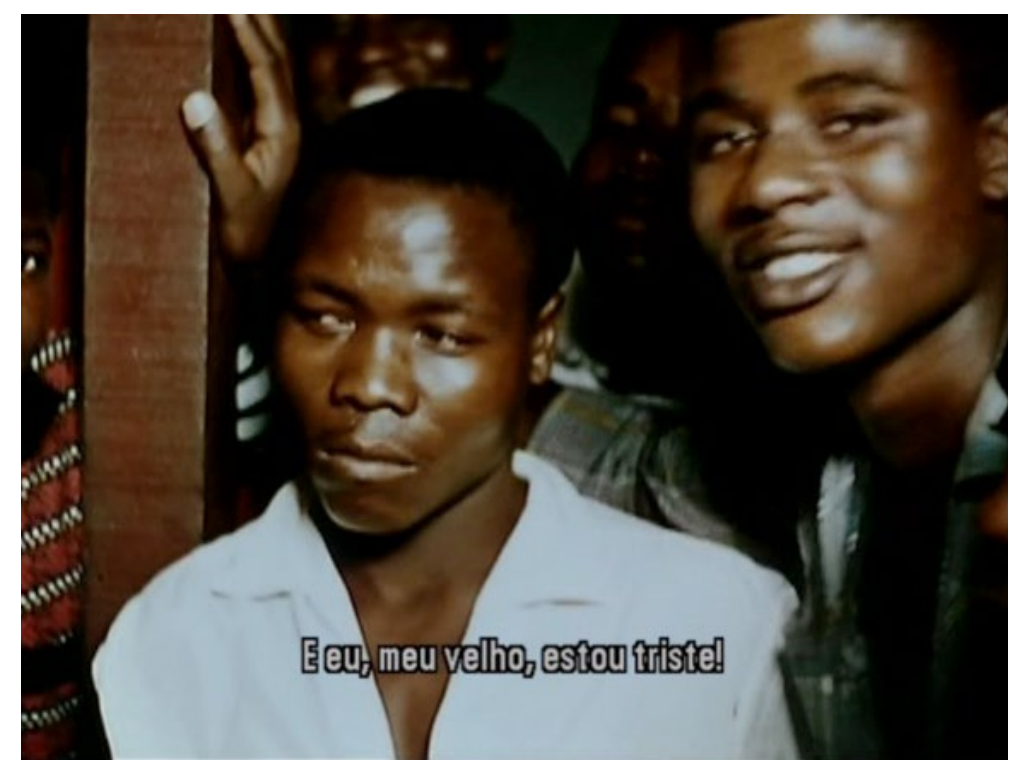

FIGURA 12 Oumarou Ganda seduzindo Dorothy Lamour. Fonte: Eu, um negro, de Jean Rouch (1958/2006).

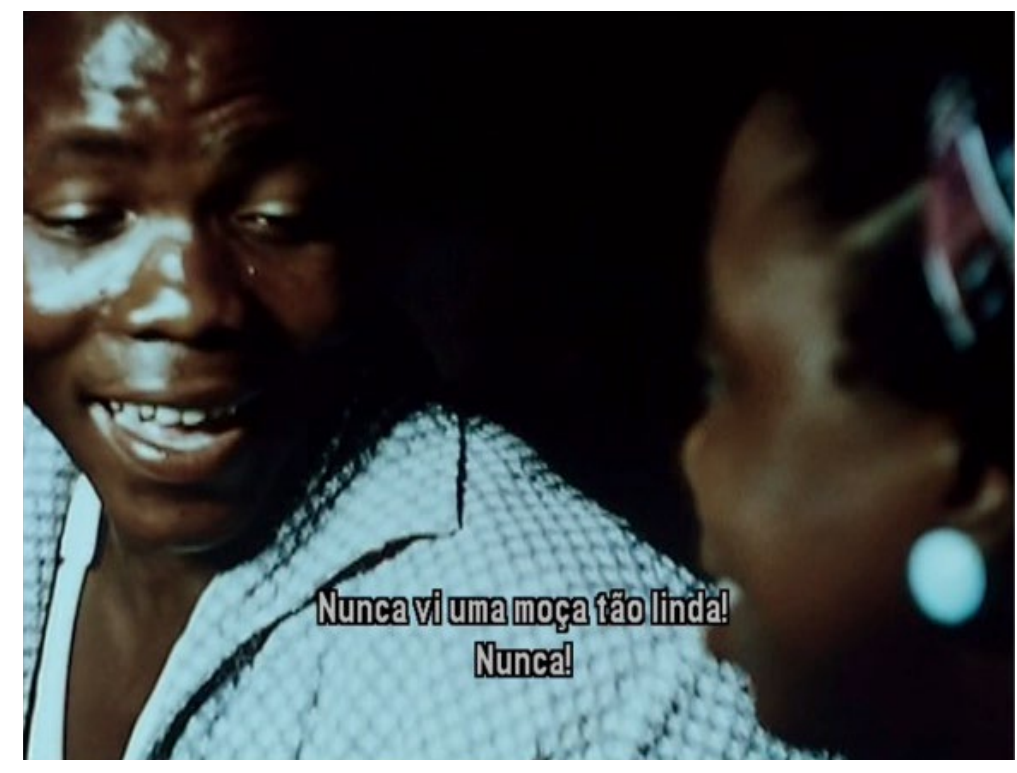


o desenlace do filme traz uma série de planos-sequência em que Robinson fabula lembranças sobre sua participação na Guerra da Indochina para Petit Jules. Entre gestos com os braços, ele se joga no chão e diz que matou um grande número de inimigos na guerra. Então um sorriso reaparece em seu rosto. A empolgação na voz off surge novamente, para encerrar o filme (Figuras 13, 14, 15, 16, 17 e 18).

FIGURA 13 Oumarou Ganda encenando sua rememoração da Guerra da Indochina. Fonte:

Eu, um negro, de Jean Rouch (1958/2006).

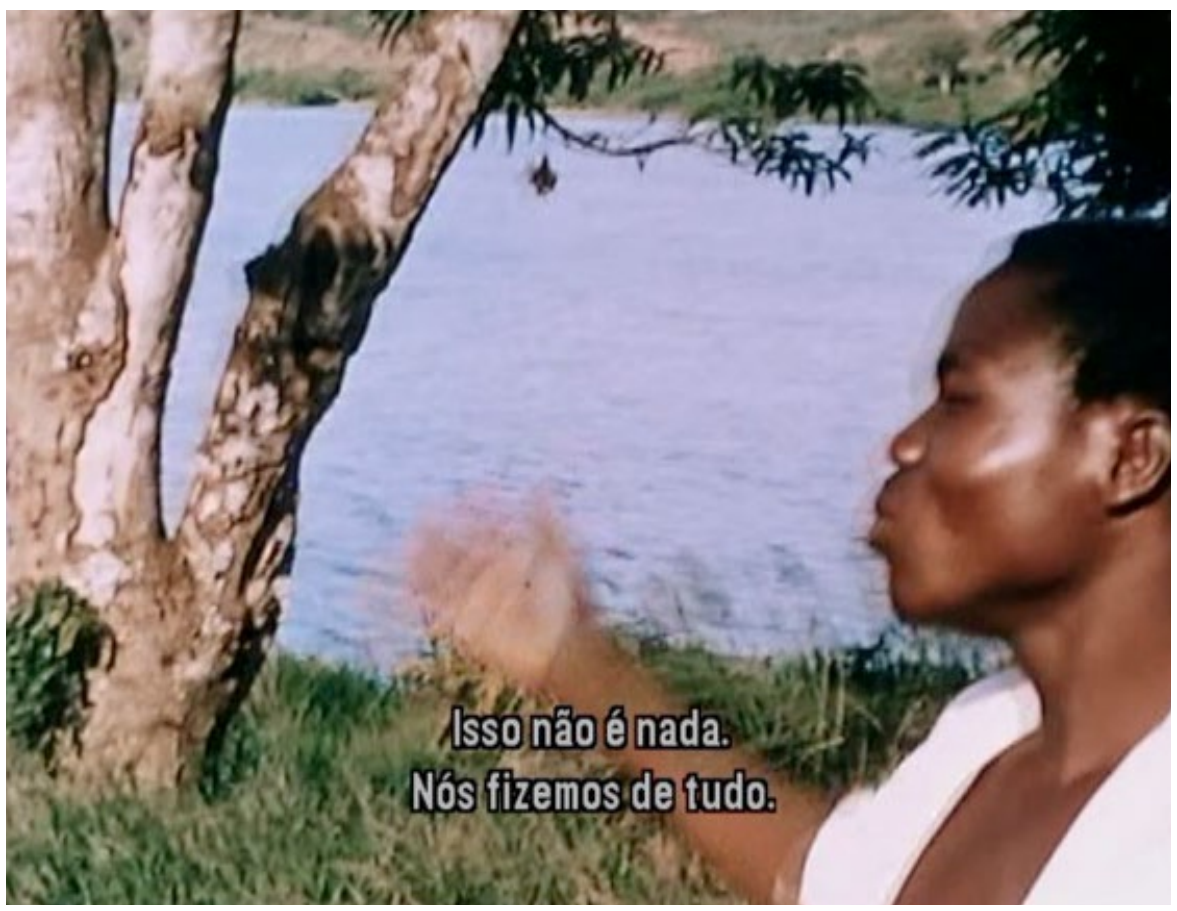

FIGURA 14 Oumarou Ganda encenando sua rememoração da Guerra da Indochina. Fonte: Eu, um negro, de Jean Rouch (1958/2006).

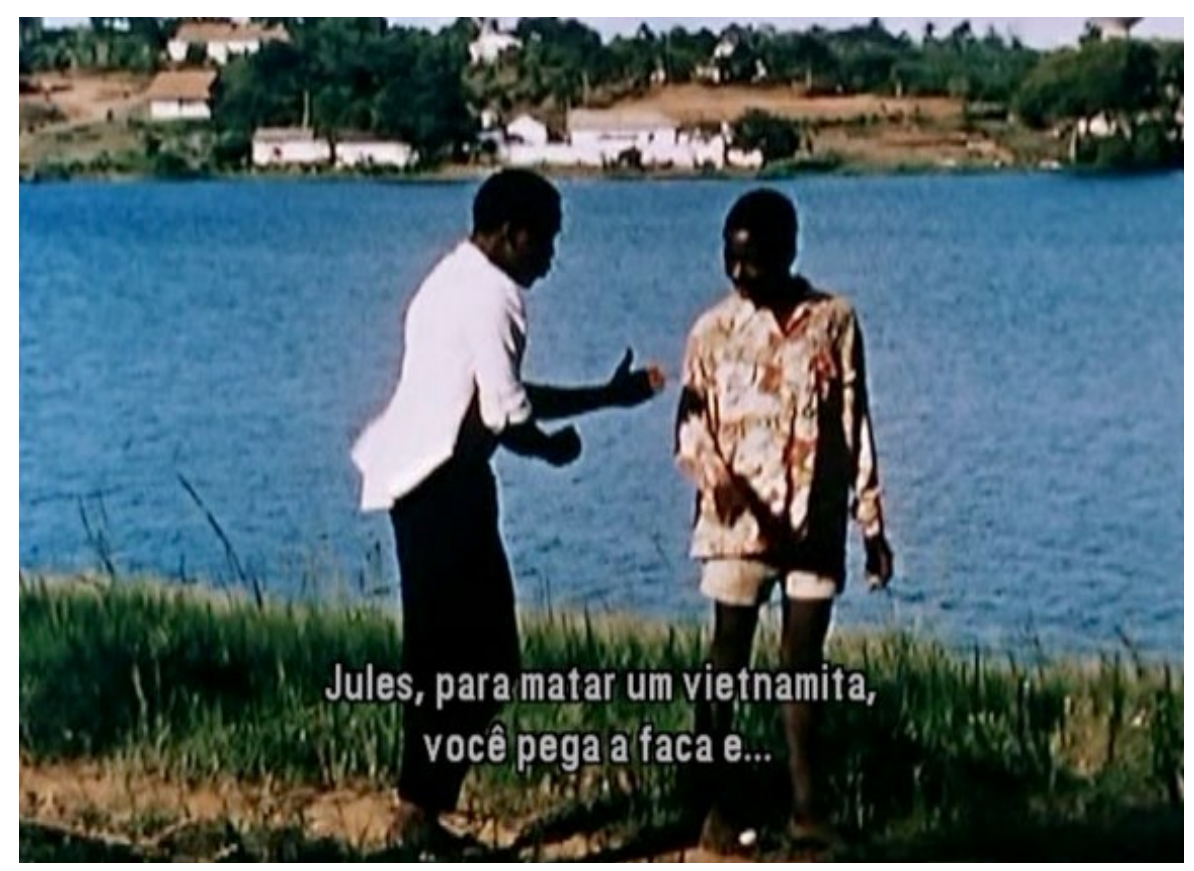




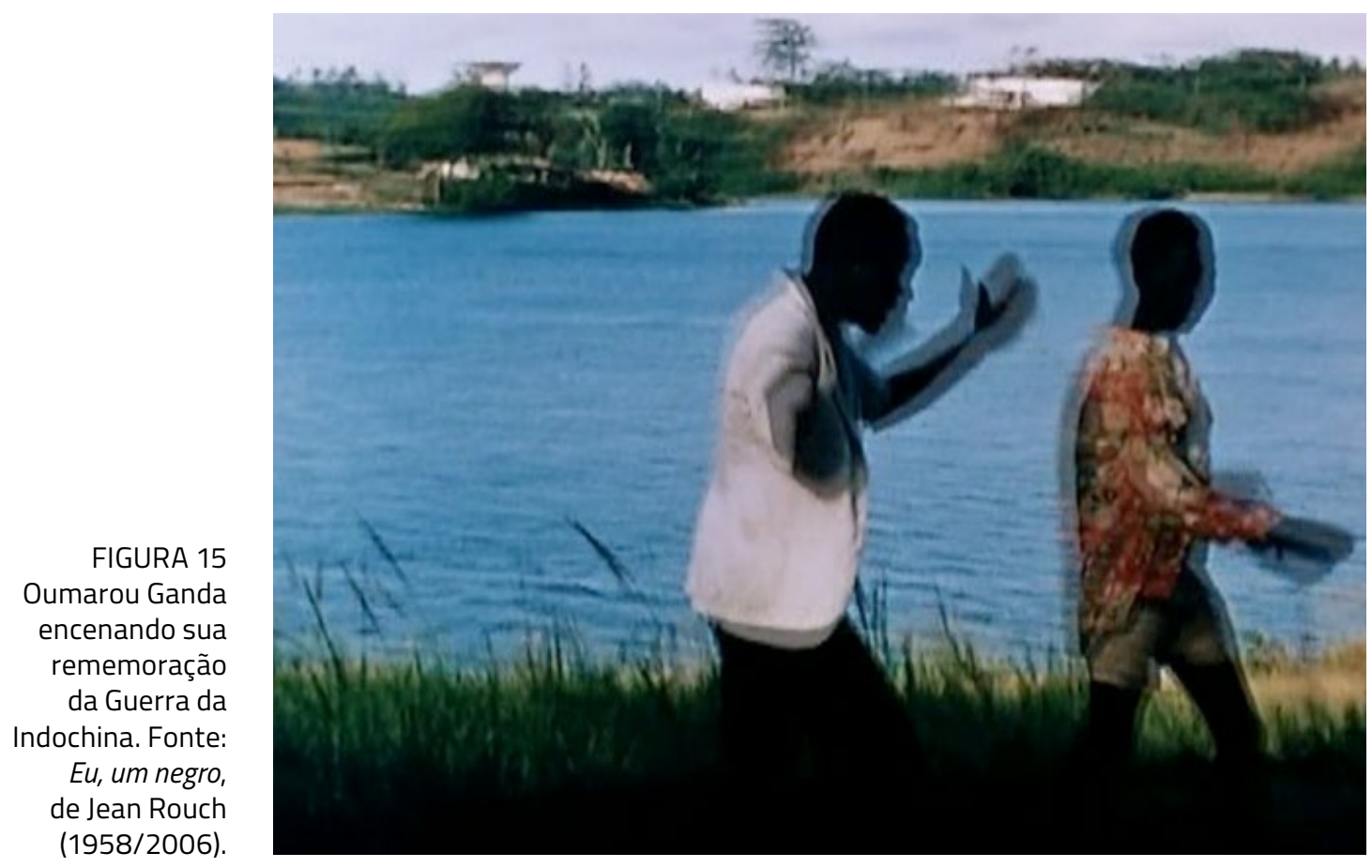

FIGURA 16 Oumarou Ganda encenando sua rememoração da Guerra da Indochina. Fonte: Eu, um negro, de Jean Rouch (1958/2006).

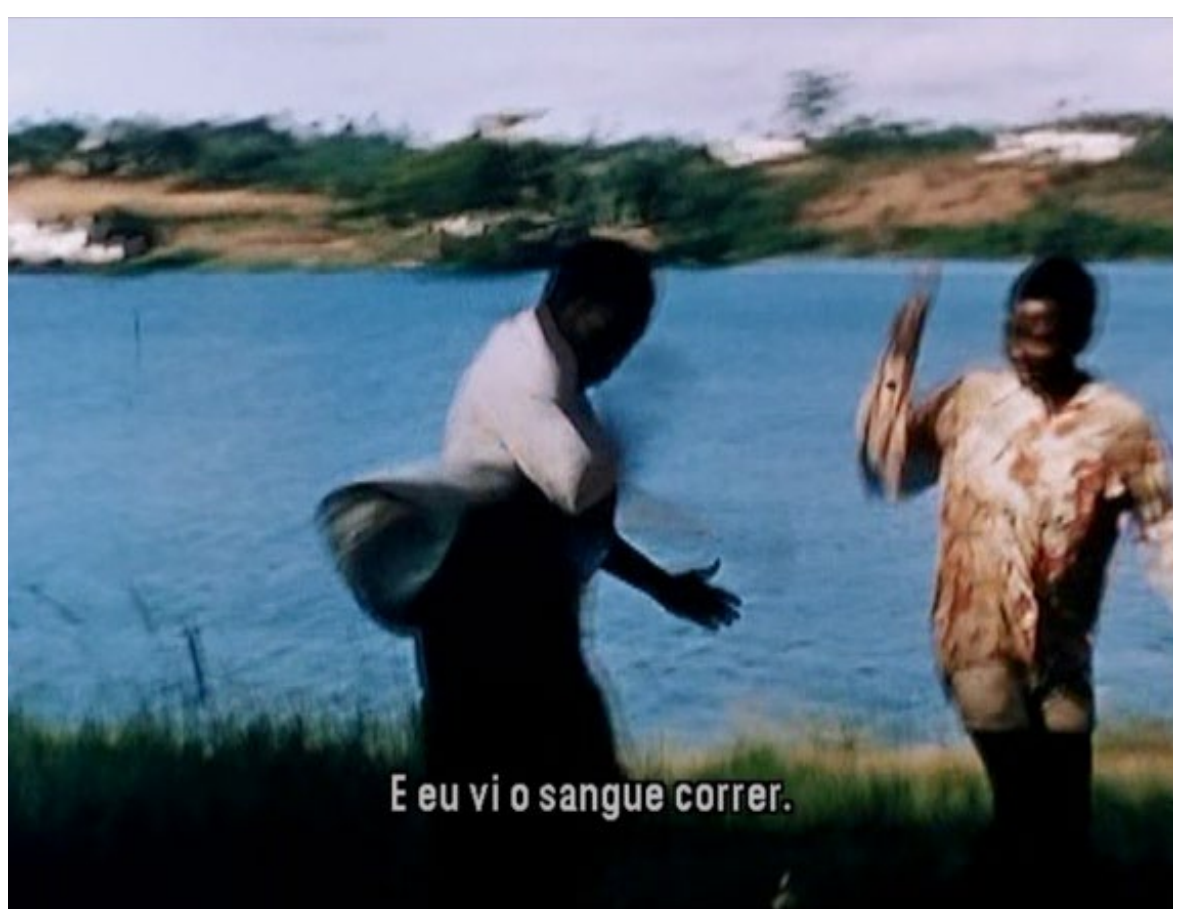




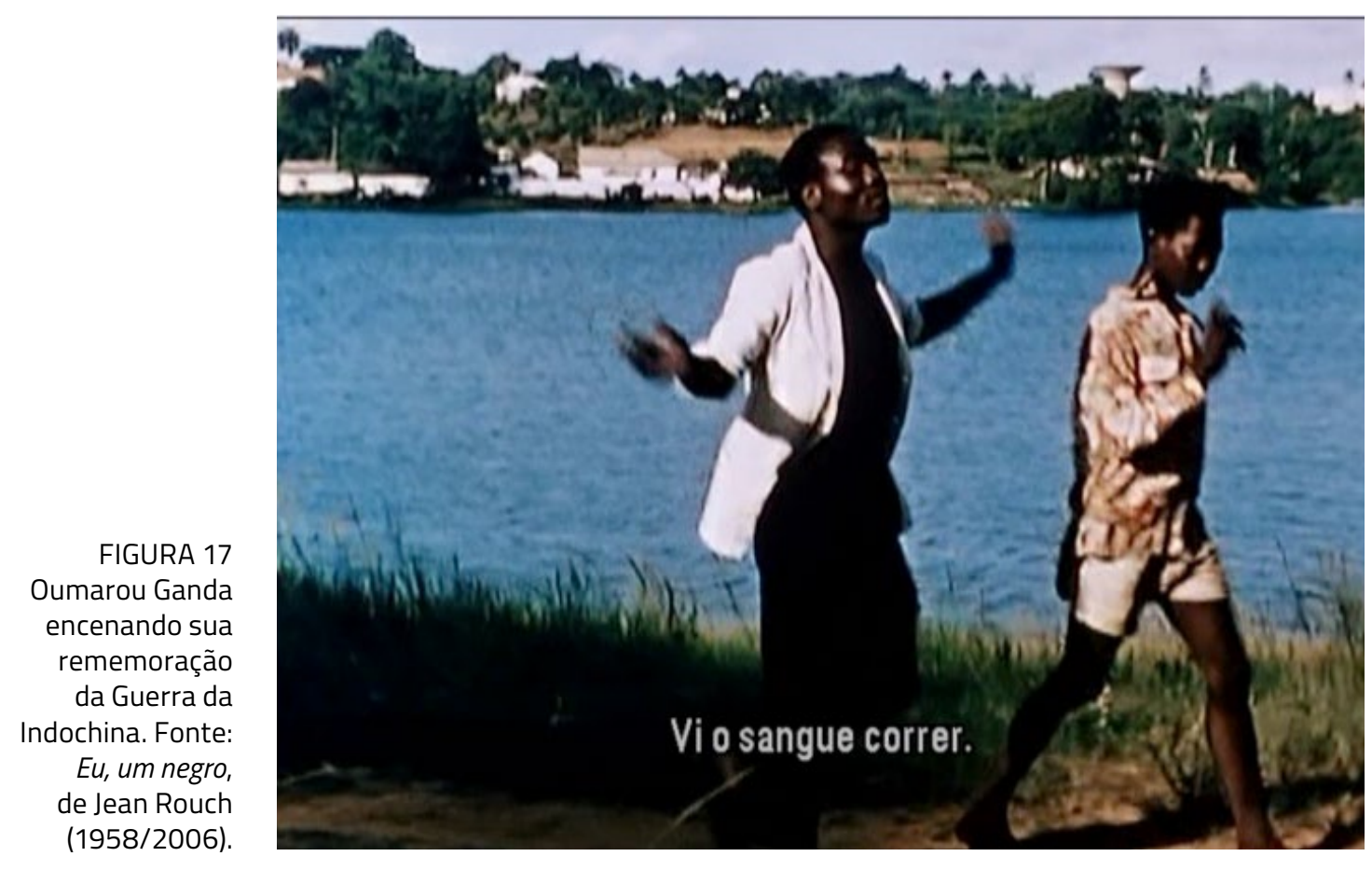

FIGURA 18 Oumarou Ganda encenando sua rememoração da Guerra da Indochina. Fonte: Eu, um negro, de Jean Rouch (1958/2006).

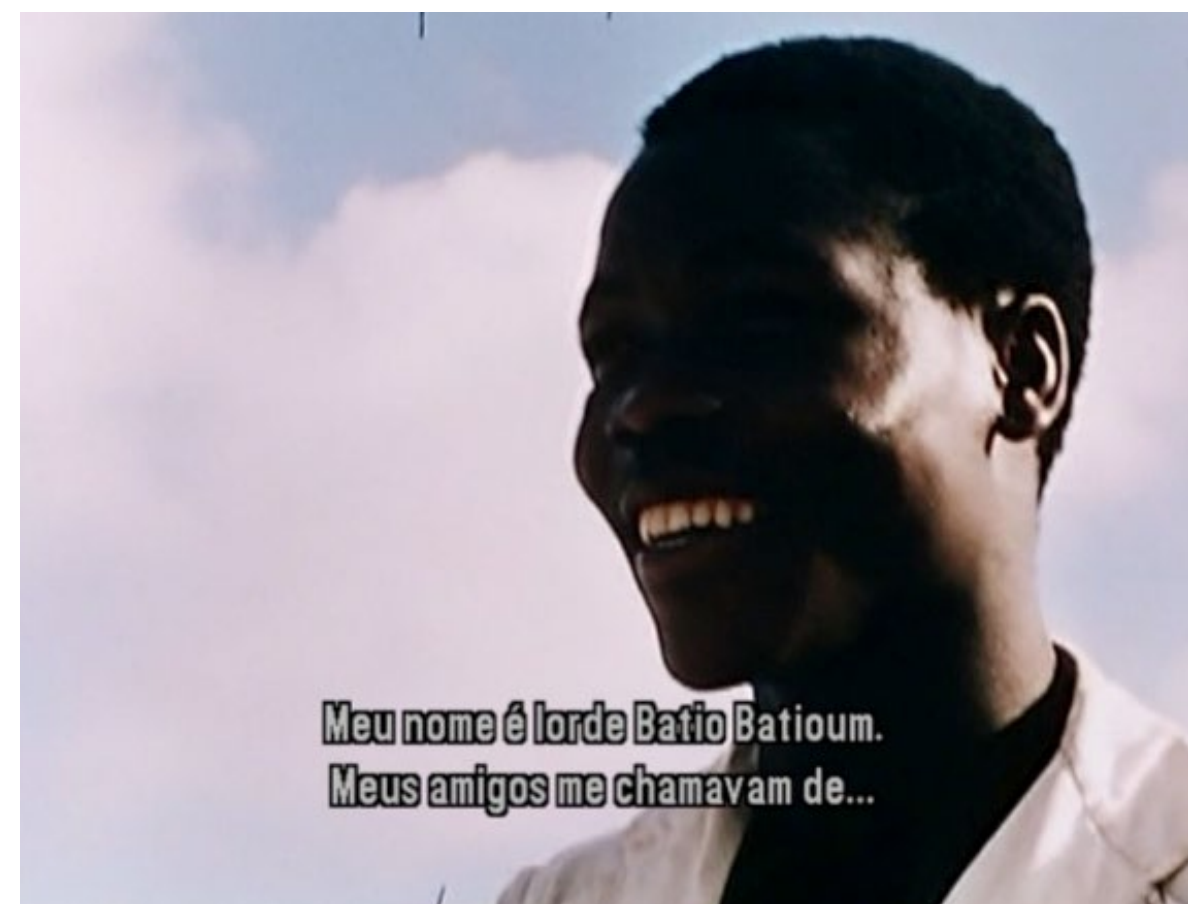




\section{CODA: O NATIVO-A(U)TOR}

É possível dizer que Oumarou Ganda desempenha três tipos de encenação para construir Edward G. Robinson: primeiro, a do cotidiano; segundo, a dimensão do sonho, intermediada pela câmera subjetiva, onde ele se torna Edward Ray Sugar Robinson, o campeão de boxe, e sonha com Dorothy Lamour. Em ambos os casos entramos na imaginação do intérprete. A última dimensão é a da memória fabulada, quando ele encena a Guerra da Indochina no contexto de seu cotidiano. Não há câmera subjetiva: apenas o vemos saltando para lá e para cá, imaginando o que ele estaria imaginando a partir de seus movimentos corporais.

Entre esses três tipos de encenação, em meio à tensão entre a realidade e a ficção, o cotidiano e o sonho, a lembrança e o devaneio, ser ele mesmo e ser outro, Oumarou Ganda modula sua expressividade. Já Petit Touré/ Constantine, ator profissional, passa a maior parte do filme na dimensão do cotidiano, mas termina numa dimensão extracotidiana, com a prisão de seu próprio personagem. Ele vai de um polo a outro e não preserva um equilíbrio instável entre as duas dimensões, tal como Oumarou Ganda/ Edward Robinson. Ambos, com suas diferenças, recriam personagens à procura de si. Eu, um negro faz a transição entre a personagem clássica do documentário, que ilustrava uma situação social, e a personagem moderna, uma figura em crise, que busca a si mesma. Nesse sentido, a interpretação de Oumarou Ganda, entre o sorriso tenso e a tristeza irônica, expressa tão bem essa transição quanto o jogo de câmeras que se vale da profundidade de campo e dos planos mais longos.

Os impactos de Eu, um negro para a Nouvelle Vague não foram poucos. A série de planos-sequência em que Ganda recorda a Guerra da Indochina inspira François Truffaut na composição da cena final de Os incompreendidos (1959), quando Antoine Doinel foge do orfanato (cf. Henley op. cit.). Jean-Luc Godard (apud Henley op. cit.) dedica não menos de três páginas de sua crítica a Eu, um negro, publicada nos Cahiers du Cinema, para exaltar a maestria de Rouch no uso da câmera, como também seu trabalho de ator. Rouch, com improviso e atores amadores, teria conseguido, segundo Godard, um resultado similar ao que o neorrealismo italiano, Pirandello e Stanislavsky obtiveram através de muito cálculo (Henley op. cit.).

Conforme mencionado no início, "A evolução da linguagem cinematográfica”, ensaio de André Bazin (2018, 117), analisa como o advento do som no cinema abriu espaço para o uso alargado do plano-sequência e da profundidade de campo, restituindo assim "a ambiguidade na estrutura da imagem, se não como necessidade, pelo menos como uma possibilidade", mas também abrindo um maior espaço de movimento para os atores em cena, que conseguem intervir com mais propriedade nos 
sentidos dados ao filme. Essas seriam as formas que a Nouvelle Vague utilizou para narrar a crise do personagem moderno. ${ }^{12}$

Não me parece exagerado dizer que, para o desenvolvimento da linguagem cinematográfica, não foi menos importante a experiência etnográfica e a proposta de antropologia compartilhada de Rouch, que resultaram num método de filmagem capaz de corporificar os saberes de seus interlocutores: seja no roteiro, escrito conforme a tradição oral, seja na adoção do modo Dogon de fabular histórias, ou ao dar espaço e liberdade ao improviso e à criação de seus atores. Em outras palavras, a proposta epistemológica de uma antropologia compartilhada através do cinema possibilitou, talvez, um cinema compartilhado através da antropologia.

Em termos de inovação antropológica, se perguntar sobre o lugar de criação de Oumarou Ganda e Petit Touré no filme igualmente traz rendimentos. Marc Piault $(1997,191)$ analisa que, dentro do contexto social de emigração dos nigerinos rumo à Costa do Marfim, à procura de trabalho, Eu, um negro mostra uma existência que é "pouco a pouco percebida como uma escolha possível, como uma construção autônoma e original, um campo de invenção, de criação e não como uma simples etapa na ordem de um determinismo geral". Oumarou Ganda "assume o estatuto de sujeito" (Ibid., 191) que se direciona ao próprio espectador, quebrando a quarta parede invisível do cinema. Nesse sentido, a antropologia compartilhada de Rouch

\begin{abstract}
não é um simples método de participação efetiva, ela dá conta do insuperável paradoxo da alteridade que a antropologia tem, justamente, por função assumir: como mostrar e entender a diferença sem a tornar irredutível, nem a reduzir ao idêntico. A questão é, igualmente, de tornar acessível a um e a Outro aquilo que lhes é estranho e mesmo de tornar acessível a Outro como a um aquilo que lhes é ainda incompreensível. (Ibid., 190)
\end{abstract}

O estatuto de sujeito de Oumarou Ganda e Touré é possibilitado justamente pela narração das sequências filmadas, mas também pelas performances como Robinson e Constantine, entre outras sequências. Eles não são apenas imigrantes, uma categoria sociológica, mas sujeitos com seus sonhos e crises diante de um cotidiano maçante. Nesse sentido, a atuação deles não é uma personalização, tampouco uma despersonalização, mas, como interpreta Gonçalves (op. cit.), inspirado em Deleuze e Parnet, ambos desempenham um devir outro:

12. Os pontos de conexão entre o cinema de Jean Rouch e a Nouvelle Vague valeriam um outro artigo. Por ora, menciono essas informações para sugerir de que modo a relação que ele construiu com seus interlocutores, advinda de uma base epistemológica da antropologia, pode ter trazido uma nova relação entre diretor e ator, especialmente no cinema francês. 
Devir é nunca imitar, nem fazer como, nem se conformar a um modelo, seja de justiça ou de verdade. Não há um termo do qual se parta, nem um ao qual se chegue ou ao qual se deva chegar. Tampouco dois termos intercambiantes. A pergunta "o que você devém?" é particularmente estúpida. Pois à medida que alguém se transforma, aquilo em que ele se transforma muda tanto quanto ele próprio. (Deleuze e Parnet 1998, 3)

Etnografar o devir, o processo de constante transformação dos sujeitos e seres, combinado com um diálogo equânime entre antropólogos e nativos, tem sido um desafio na antropologia contemporânea. Como notou Renato Sztutman (2004), Jean Rouch já era figura bastante conhecida no cinema dos anos 2000 entre documentaristas brasileiros investigativos. Já para a antropologia brasileira, sua contribuição ainda estaria por ser revelada. Se atualmente o diretor se tornou uma referência também para antropólogos e antropólogas no Brasil, é possível que isso tenha acontecido na medida em que, como mostra Sztutman (Ibid., 52), o projeto rouchiano de antropologia mirava "a possibilidade de criação de um diálogo com a sociedade estudada, no caso, potencializada pelo cinema” - algo cada vez mais presente. É interessante, do ponto de vista da antropologia, que a teoria, para Rouch, seja "incluída na práxis do cinema, essa sim a condição de produção de um conhecimento passível de ser compartilhado, aquele que se constrói na mão-dupla entre observadores e observado" (Ibid., 52).

Mais do que conclusões, contudo, restam perguntas. Em que medida seria possível dizer que o filme $\mathrm{Eu}$, um negro é uma maneira de trair a nossa língua a partir da língua do outro, ou de evidenciar momentos em que "a forma intrínseca à matéria do primeiro [nativo] modifica a matéria implícita na forma do segundo [antropólogo]”, nas palavras de Eduardo Viveiros de Castro $(2002,115)$ ?

Mesmo que essas propostas de antropologia soem, por vezes, distantes de Rouch, a aproximação parece-me possível, uma vez que Eu, um negro procurou "trair" os cânones daquilo que o cinema de seu tempo definiu como documentário e ficção, e a antropologia, como ciência e arte. $^{13}$ Essa tradução/traição, aliás, porquanto almejava um modo de acessar aquilo que realmente importava para os atores em cena, e não apenas aquilo que o diretor elegeu como problema etnográfico, ${ }^{14}$ tam-

13. Conforme Renato Sztutman $(2004,52)$, para Rouch "seria possível pensar na convergência de interesses entre o cientista e o artista, e desse intercurso poderia revelar-se uma nova antropologia”. Em relação à arte, Sztutman (Ibid., 52) destaca: “Com Rouch [...] a arte pode se satisfazer com o acaso, a mise-en-scène se abre para o contingente e transforma-se em algo entre a ficção e o documentário".

14. "A 'arte da antropologia' [...], penso eu, é a arte de determinar os problemas postos por cada cultura, não a de achar soluções para os problemas postos pela nossa" (Viveiros de Castro 2002 , 117). Rouch, em Eu, um negro, ao compartilhar a narração do filme com Oumarou Ganda e Petit Touré, dá vazão para os problemas postos pelos migrantes nigerinos em Abidjan. 
bém colocava em xeque o próprio projeto antropológico: nem a premissa modernista de que é possível conhecer o outro cientificamente (ou artisticamente), nem a pós-moderna, que propõe "dar voz ao nativo" - sem necessariamente se perguntar sobre os modos de conhecer e fabular dos nativos (Strathern 1982; 2013) -, se encaixam bem nesse tipo de cinema. Entretanto, há ali uma criação conjunta, que desnorteia ao questionar, do ponto de vista formal e conceitual, sua condição de existência. A voz off de Rouch visa contextualizar, para o espectador europeu, a situação desses imigrantes, mas não compete com as performances e as narrações de Oumarou Ganda e Petit Touré.

A verdade no documentário - um problema sempre presente na discussão sobre esse gênero - se torna, no encontro de Rouch com Ganda, Touré e outros, um conceito, ele próprio, fabulado. Como propõe Sztutman $(2005,122)$, não se fala ali de "uma verdade nua, mas uma verdade fílmica, uma verdade do cinema. Não de uma verdade visível, mas uma verdade que deve ser descortinada, inacessível ao olho senão pela mediação da câmera. A essa verdade se acede, vale ressaltar, pelo imaginário e pela imaginação".

Se é possível considerar que essa verdade é de autoria tanto de Rouch quanto de Oumarou Ganda e Petit Touré, talhada por cada um e por cada qual a seu modo; e se é possível que Ganda e Touré sejam considerados atores-autores nesse filme, fica uma última questão: seria igualmente possível transformar a fórmula "nativo-a(u)tor", à qual se refere o título deste artigo, em "nativo-antropólogo"? Se, de fato, Rouch, Ganda e Touré tensionam a nossa língua e a linguagem cinematográfica em $\mathrm{Eu}$, um negro, parece-me que essa etnoficção alcança, em termos etnográficos e cinematograficamente, essa transformação - algo impossível sem a presença dos três.

\section{REFERÊNCIAS BIBLIOGRÁFICAS}

Arnheim, Rudolf. 1957. Film as art. Berkeley: University of California Press.

Baron, Cynthia and Sharon Marie Carnicke. 2008. Reframing screen performance. Ann Arbor: University of Michigan Press.

Bazin, André. 2006. Orson Welles. Rio de Janeiro: Zahar.

Bazin, André. 2018. O que é o cinema? São Paulo: Ubu.

Benjamin, Walter. 1987. A obra de arte na época de sua reprodutibilidade técnica. In Magia, técnica, arte e política: ensaios sobre literatura e história da cultura, Walter Benjamin, 167-196. São Paulo: Brasiliense.

Bhabha, Homi. 2007. O local da cultura. Belo Horizonte: Ed. UFMG.

Boudreault-Founier, Alexandrine, Rose Satiko Gitirana Hikiji e Sylvia Caiuby Novaes. 2016. Etnoficção: uma ponte entre fronteiras. In A experiência da imagem na etnografia, ed. Andrea Barbosa, Edgar Teodoro da Cunha, Rose Satiko Gitirana Hikiji e Sylvia Caiuby Novaes, 37-58. São Paulo: Terceiro Nome. 
Deleuze, Gilles e Claire Parnet. 1998. Diálogos. São Paulo: Escuta.

Eisenstein, Sergei.1957. The film sense. New York: Meridian Books.

Ferraz, Ana Lúcia M. C. 2013. Dramaturgia da vida social e a dimensão patética da pesquisa antropológica: o cinema de Jean Rouch e a prática de realização de filmes etnográficos. In Antropologia e performance: ensaios Napedra, org. John Cowart Dawsey, Rose Satiko Gitirana Hijiki, Marianna Monteiro e Regina Polo Muller, 323-338. São Paulo: Terceiro Nome.

Gonçalves, Marco Antonio. 2008. O real imaginado: etnografia, cinema e surrealismo em Jean Rouch. Rio de Janeiro: Topbooks.

Grimshaw, Anna. 2001. The ethnographer's eye: ways of seeing in anthropology. Cambridge: Cambridge University Press.

Hall, Stuart, org. 1997. Representation: cultural representation and signifying practices. London: Sage.

Henley, Paul. 2009. The adventure of the Real: Jean Rouch and the Craft of Ethnographic Cinema. Chicago, London: University of Chicago Press.

Hirano, Luis Felipe Kojima. 2019. Grande Otelo: um intérprete do cinema e do racismo no Brasil (1917-1993). Belo Horizonte: Ed. UFMG.

Hirano, Luis Felipe Kojima. 2013. O imaginário da branquitude à luz da trajetória de Grande Otelo: raça, persona e estereótipo em sua perfomance artística. AfroÁsia, no. 48: 77-125. http://dx.doi.org/10.1590/S0002-05912013000200003.

Ingold, Tim. 2007. Lines. London: Routledge.

Ingold, Tim. 2015. The life of lines. London: Routledge.

King, Barry. 1985. Articulating Stardom. Screen, vol. 26, no. 5: 27-50.

Kuleshov, Lev. 1974. Kuleshov on film: writings of Lev Kuleshov. Los Angeles: University of California Press.

Lotierzo, Tatiana. 2019. Erosão num pedaço de papel. Tese de doutorado, Universidade de Brasília, Brasília.

Marcus, George. 1991. Identidades passadas, presentes e emergentes: requisitos para etnografias sobre a modernidade no final do século XX ao nível mundial. Revista de Antropologia, vol. 34: 197-221. https://doi.org/10.11606/2179-0892. ra.1991.111301.

Mauss, Marcel. 1934/2003. As técnicas do corpo. In: Ensaios de sociologia e antropologia. São Paulo: Cosac Naify.

Piault, Marc-Henri.1997. Uma antropologia-diálogo: a propósito do filme de Jean Rouch, Moi, un noir. Cadernos de Antropologia e Imagem, no. 4: 185-192.

Pirandello, Luigi. 1925. On tour. Paris: Sagittaire.

Stam, Robert e Ella Shohat. 2006. Crítica da imagem eurocêntrica. São Paulo: Cosac Naify.

Strathern, Marilyn. 2013. Fora de contexto. São Paulo: Terceiro Nome.

Strathern, Marilyn. 1982. The limits of autoanthropology. In Anthropology at home, ed. Anthony Jackson, 16-37 London: Tavistock Publications.

Sztutman, Renato. 2004. Jean Rouch: um antropólogo-cineasta. In Escrituras da imagem, ed. Sylvia Caiuby Novaes, Andréa Barbosa, Edgar Teodoro da Cunha, Florencia Ferrari, Renato Sztutman e Rose Satiko Gitirana Hikiji, 49-62 São Paulo: Edusp. 
Sztutman, Renato. 2005. Imagens perigosas: a possessão e a gênese do cinema de Jean Rouch. Cadernos de Campo, vol. 13, no. 13: 115-124. https://doi.org/10.11606/ issn.2316-9133.v13i13p115-124.

Viveiros de Castro, Eduardo. 2002. O nativo relativo. Mana, vol. 8, no. 1: 113-148. https:// dx.doi.org/10.1590/S0104-93132002000100005.

Xavier, Ismail. 2005. O discurso cinematográfico. São Paulo: Paz e Terra.

\section{REFERÊNCIAS AUDIOVISUAIS}

Ferraz, Ana Lúcia, Edgar Teodoro da Cunha, Paula Morgado e Renato Sztutman. 2000. Jean Rouch: subvertendo fronteiras. São Paulo, Brasil, NTSC, cor, 41', DVD.

Kurosawa, Akira. 1954/2004. Os sete samurais. São Paulo, Brasil, Silverscreen, P\&B, 207', DVD.

Rouch, Jean. 1958/2006. Eu, um negro. Rio de Janeiro, Brasil, VideoFilmes, cor, 78', DVD.

Sturges, John. 1960/2007. The magnificent seven. Los Angeles, EUA, United Artists, P\&B, 128', DVD.

Truffaut, François. 1959/2003. Os incompreendidos. São Paulo, Brasil, MK2, P\&B, 100', DVD.

LUIS FELIPE KOJIMA HIRANO é professor de Antropologia da Universidade Federal de Goiás (UFG). Bacharel em Ciências Sociais e doutor pela Universidade de São Paulo (USP). Foi FAS Fellow da Universidade de Harvard. Atualmente, realiza pesquisa de pós-doutorado pelo Programa de Pós-Graduação em Antropologia Social da USP sobre antropologia visual e antropologia da percepção. É autor do livro Grande Otelo: um intérprete do cinema e do racismo no Brasil, publicado pela Editora UFMG, organizou a coletânea Marcadores sociais das diferenças: fluxos, trânsitos e intersecções, pelo Cegraf-UFG, e publicou artigos que articulam o tema da intersecção entre raça, gênero, corpo e sexualidade nas trajetórias e performances de atores e atrizes do cinema. E-mail: Ifhirano@ufg.br 